\title{
Inovações técnicas e atitudes intelectuais na literatura açucareira francesa e luso-brasileira da primeira metade do século XVIII *
}

Rafael de Bivar Marquese

Doutorando em História Econômica - FFLCH/USP
* Este artigo faz parte de uma pesquisa mais ampla que conta com o financimanto da Fundação de Amparo à Pesquisa do Estado de São Paulo (FAPESP).

Introdução

Em fins do século XVl, após quatro décadas do início de sua colonização efetiva, a América portuguesa era a principal fornecedora de açúcar no mercado europeu, com uma produção que superava o total combinado de todas as regiões produtoras do Atlântico no período (llhas da Madeira, de São Tomé e Hispaniola). Com efeito, a costa nordeste do litoral brasileiro foi o primeiro pólo de produção em larga escala do açúcar no Novo Mundo. A produção dos espanhóis no Caribe, estabelecida na década de 1510, malogrou diante da concorrência do açúcar brasileiro a partir do último quarto do século XVI.

Na passagem do século XVI para o XVII, a América portuguesa também foi um importante centro de inovação técnica na manufatura açucareira. A base técnica dos engenhos de açúcar americanos, nas décadas iniciais do estabelecimento da indústria no Novo Mundo, era tributária dos processos empregados no Mar Mediterrâneo. No caso da moagem da cana, por exemplo, ainda no final do século XVI a produção espanhola e portuguesa no Atlântico se valia das técnicas utilizadas originalmente no Mediterrâneo, e que haviam sido adaptadas à produção açucareira a partir de mecanismos concebidos para outros processos de beneficiamento, como as moendas de olivas e uvas (GALLOWAY, 1989, p.37). Nas décadas de 1610 e 1620, a adoção da moenda vertical de entrosas de três rolos nos engenhos brasileiros representou uma profunda ruptura com os padrões técnicos anteriores. Por conta dos ganhos 
de produtividade, este mecanismo de moagem se espalhou com relativa rapidez por todas as regiões produtoras de açúcar nas Américas, e acabou por se converter no tipo de moenda adotado até o final do século XVIII nos engenhos do Novo Mundo (CASTRO, 1980).

O monopólio da América portuguesa no mercado europeu de açúcar foi mantido durante toda a primeira metade do século XVII. A região, contudo, logo perdeu a dianteira: na segunda metade do século XVII, as colônias inglesas e francesas do Caribe, apropriando-se de técnicas provenientes do Brasil, passaram a produzir açúcar em larga escala. Na passagem do século XVII para o XVIII, e ao longo de todo o século XVIII, a produção das Antilhas francesas e inglesas não só relegou o açúcar brasileiro a um segundo plano no mercado internacional, como igualmente implementou uma série de inovações técnicas, enquanto na América portuguesa foram conservadas as técnicas anteriores.

A perda do controle do mercado al ântico de açúcar pela produção brasileira durante o século XVIII, e, principalmente, o problema do atraso técnico de sua agromanufatura em relação à das Antilhas, foram objetos de observação no Brasil desde o final dos setecentos. Reformadores ilustrados da agricultura escravista brasileira, como Frei José Mariano da Conceição Velloso e Luís dos Santos Vilhena (VELLOSO, 1798-1800, VILHENA, 1969), ou mesmo viajantes estrangeiros que estiveram no Brasil no início do século XIX, como Henry Koster (KOSTER, 1817), haviam enfatizado que a produção brasileira de açúcar deveria se inspirar nas técnicas mais avançadas das Antilhas francesas e inglesas. Esta mesma recomendação esteve presente nas publicações agronômicas brasileiras referentes ao produto durante todo o século XIX (RODRIGUES, 1942).

No século XX, o tema passou à alçada dos historiadores. Na historiografia contemporânea, pode-se afirmar que a inauguradora do exame do problema foi Alice Piffer Canabrava, num trabalho de 1946. O estudo de Canabrava teve por escopo a análise da indústria açucareira e suas técnicas produtivas nas Antilhas francesa e inglesa na primeira metade do século XVIII. Neste trabalho, a historiadora também analisou as técnicas dos engenhos brasileiros, pois estas the serviram para precisar qual foi o avanço produtivo representado pela produção antilhana.

Canabrava fundamentou sua explicação para o avanço técnico obtido pelas Antilhas em relação ao Brasil nas condições geográficas específicas de cada uma das regiões. Assim, enquanto no Brasil a abundância de terras não forçou os proprietários rurais a utilizar o estrume para a fertilização do solo destinado ao plantio da cana, no Caribe "a escassez de novas áreas de expansão e o fenômeno generalizado do esgotamento das terras nas mais velhas zonas de produção do açúcar do século XVIII, condicionaram desde cedo (...) o emprego de fertilizantes" (CANABRAVA, 1981, p.80). Um outro exemplo lembrado por Canabrava reside no uso do combustivel das fornalhas. Dada a carência de matas nas Antilhas, e, portanto, de lenha, os senhores de engenho dessa região, desde o final do século XVII, viram-se obrigados a lançar mão do bagaço da cana como combustível para o aquecimento das caldeiras destinadas a preparar o açúcar; associado ao uso do bagaço, logo se inventou uma nova disposição das fornalhas, o chamado "forno inglês", ou "trem jamaicano", que possibilitava uma enorme economia de combustivel (pp. 136-141). 
Sem sombra de dúvidas, a inovadora pesquisa de Alice Canabrava fixou os termos pelos quais o assunto foi tratado até a década de 1980. Veja-se, por exemplo, o artigo de 1979 de Ciro Flamarion Cardoso, que buscou conferir maior sofisticação teórica à corrente interpretativa inaugurada por Canabrava. Após fazer um inventário das discrepâncias nos níveis técnicos das lavouras açucareiras escravistas do Novo Mundo, apontando com especial insistência "a superioridade das técnicas das Antithas inglesas e francesas em relação às do Brasil", Cardoso elaborou um modelo explicativo para tanto. Segundo ele, o historiador, para entender a adoção diferencial de técnicas produtivas inovadoras, deve levar em conta não só os fatores naturais específicos de cada região, mas também a articulação de cada uma delas com o mercado mundial; desta forma, além das condições naturais adversas das Antilhas terem forçado os proprietários desta região a adotarem a adubação dos canaviais e o uso do bagaço como combustivel, a "fase de grande expansão (...) de sua economia, de fins do século XVIl a fins do século seguinte", ao ser "acompanhada por um enorme movimento comercial e de capitais", permitiu aos senhores escravistas franceses e ingleses a implementação técnica de suas propriedades (CARDOSO, 1979, pp. $111-1321$.

Mais recentemente, John $H$. Galloway retomou a análise das inovações técnicas nas propriedades açucareiras do Novo Mundo. Num artigo cujo objeto é a "tradição e inovação na indústria açucareira americana" entre 1500 e 1800, Galloway procurou fornecer uma visão global das técnicas açucareiras nas Américas. Calcado na verificação de que nos três primeiros séculos da indústria sacarífera no Novo Mundo os proprietários rurais escravistas adotaram inovações no uso da terra e no processamento da cana de forma diferencial, isto é, inovando em algumas colônias e em outras não, ou mesmo modificando ao longo do tempo a disposição para aplicá-las, Galloway propôs um modelo explicativo para a difusão destas inovações que leva em conta não só a sua adoção em diferentes tempos e espaços, mas também a persistência de práticas tradicionais em colônias específicas (GALLOWAY, 1985, pp. 334-335). Galloway tem como ponto de partida da sua argumentação a racionalidade econômica dos senhores na gestão de suas propriedades. Assim, os proprietários escravistas, tendo acesso às informações sobre novas técnicas produtivas, sempre as empregariam caso houvesse boa expectativa na obtenção de retorno do investimento feito. As variáveis que delimitariam as estratégias gerenciais dos senhores seriam basicamente duas: 11 a disponibilidade de recursos naturais; 2l o tipo de mercado para o qual se destinaria a produção, isto é, ou mercados locais não-competitivos ou mercado internacional competitivo. Resultam destas variáveis as três hipóteses explicativas de seu modelo:

"11) As inovações que possibilitam a obtenção de lucros líquidos elevados para todos os proprietários, indiferentemente de considerações sobre recursos naturais ou mercados, difundem-se rapidamente pela indústria.

(2) A escassez ou o esgotamento de recursos naturais estimula a adoção de inovações.

(3) A competição no mercado estimula a adoção de inovações." (p.337)

Estas hipóteses tornam inteligível o atraso técnico brasileiro em relação às Antilhas francesas e inglesas no século XVIII, aparentemente paradoxal quando 
se tem em conta o papel inovador que a indústria brasileira desempenhou no começo do século XVII. Os proprietários brasileiros, segundo Galloway, tornaramse menos inovadores na medida em que o açúcar de seus engenhos foi perdendo espaço no competitivo mercado europeu para os concorrentes antilhanos, ao mesmo tempo em que os recursos naturais da costa brasileira - terras férteis e matas com lenha - continuaram abundantes.

Após testar suas hipóteses na análise do movimento concreto da adoção das inovações técnicas em diferentes regiões, Galloway resumiu sua argumentação:

\footnotetext{
"Lucros líquidos altos, recursos naturais escassos ou exauridos, e participação em mercados competitivos estimulam os proprietários a inovar; lucros líquidos baixos, recursos abundantes, e mercados não-competitivos estimulam o tradicionalismo.

(...) os proprietários adotam rapidamente as inovaçōes que facultam a obtenção de lucros líquidos altos a despeito de recursos ou mercados; as outras inovaçōes, adotam seletivamente levando em conta a disponibilidade de recursos e as forças do mercado" (p.347)
}

modelo explicativo de Galloway é muito sugestivo para a compreensão do tópico das inovações técnicas na agromanufatura açucareira do Novo Mundo. Contudo, algumas considerações devem ser acrescentadas ao seu modelo, particularmente no que se refere ao seu ponto de partida

Tendo como pano de fundo essas questões historiográficas, o que se pretende discutir no presente artigo é justamente o problema da racionalidade econômica dos senhores na busca da inovação técnica. Não se pode dar por suposto a existência de uma racionalidade econômica única, num período de três séculos, para todos os proprietários e todas as regiōes escravistas do Novo Mundo. São necessárias investigações para verificar se houve de fato uma racionalidade econômica comum a todos os senhores escravistas americanos, ou se é possivel, pelo contrário, notar clivagens na racionalidade econômica das diferentes classes proprietárias das Américas. $\bigcirc$ tópico das técnicas açucareiras pode ser de especial relevância para se iniciar uma investigação desse tipo, visto que a análise da racionalidade econômica dos senhores envolve, entre outras coisas, o estudo das atitudes intelectuais coevas frente às inovações nas técnicas produtivas.

Maurice Godelier, em seus estudos de antropologia econômica, oferece elementos teóricos significativos para o exame do problema da inovação técnica, ao explorar as relações entre pensamento, economia e sociedade, e, em especial, ao analisar o peso respectivo do mental e do material nas relações sociais e na mudança das sociedades. Segundo Godelier, toda ação material dos seres humanos sobre a natureza é executada acionando realidades mentais, representações, princípios de pensamento: no centro de nossas relações com a natureza e nas próprias relações sociais há um componente mental básico, que é não só uma das condições para o surgimento e a reprodução dessas relações, mas também o próprio esquema organizativo interno de tais relações, a sua porção que existe no pensamento e que portanto a ele pertence. Isto não significa afirmar que todas as relações sociais sejam redutiveis ou reduzíveis ao pensamento, mas sim que o pensamento não existe como uma instância separada das demais relações sociais (GODELIER, 1986, pp. 10-11). 
Tais considerações ampliam a noção de forças produtivas. Estas passam a englobar tanto os recursos materiais los próprios seres humanos em si, com seus corpos e capacidades; os meios materiais interpostos pelos seres humanos entre eles e a natureza com o objetivo de agir sobre a últimal quanto um diversificado conjunto de representações, idéias e idealizações que estão conectadas com as regras que governam a feitura dos instrumentos, as alitudes corporais, e as concepções acerca da natureza. "Dentro de todas as atividades humanas sobre a natureza", escreveu Godelier, "está presente um complexo conjunto de realidades mentais cuja presença e intervenção é fundamental para que tal atividade ocorra" (pp. 13 1-132). O elemento mental, por conseguinte, ocupa uma posição capital - mas não exclusiva - no conjunto das forças produtivas disponíveis. Na medida que as representações mentais também são idéias expressas na linguagem, e, como tais, fundamentais para a transmissão e conservação das forças produtivas, pensamento e linguagem são partes necessariamente integrantes das forças produtivas (pp. 136-137)!

Portanto, ao examinar as técnicas empregadas numa determinada sociedade, o investigador deve prestar atenção às representações, idealizações e princípios de pensamento ligados a essas técnicas. $O$ incremento técnico não pode ser entendido como uma simples resposta às constrições do meio geográfico ou às forças do mercado: para compreender por que num determinado período alguns grupos humanos adotam inovaçōes e outros não, deve-se levar em conta também a esfera do mental, isto é, o conjunto de atitudes mentais que ordenam a forma de apreender as técnicas de produção.

objetivo do presente artigo é o de efetuar uma análise de duas diferentes atitudes mentais frente às técnicas produtivas açucareiras nas Antilhas e no Brasil no início do século XVIII. Estas duas formas bem distintas de apreender as técnicas dos engenhos são facilmente identificáveis nos dois relatos mais significativos sobre a produção de açúcar escritos em francês e português até a metade do século XVIII, a saber, o texto de Jean Baptiste Labat, de 1722, e o de André João Antonil, de 1711 . Sem nenhuma ambição de esgotar o assunto, o artigo pretende tão-somente indicar a necessidade de se examinar com maior vagar o problema da racionalidade econômica dos proprietários escravistas do Novo Mundo na busca da inovação técnica.

Enunciado o objetivo nesses termos, resta esclarecer ao leitor como os textos de Antonil e Labat, concebidos como um conjunto de regras destinadas a serem seguidas pelos senhores no governo de suas unidades produtivas, se articulam com a racionalidade econômica dos proprietários escravistas do Novo Mundo. Na verdade, os dois livros, ao procurarem intervir nas práticas administrativas senhoriais, tiveram que se ajustar aos padrões gerenciais concretos vigentes nos engenhos brasileiros e antilhanos. Assim, Antonil construiu sua narrativa a partir da observação minuciosa do processo produtivo do engenho Sergipe do Conde lestimado como o mais importante do Recôncavo baianol, ao mesmo tempo em que foi pragmático ao tratar das questões morais relacionadas ao governo dos engenhos brasileiros. Labat, por sua vez, foi administrador de engenho na Martinica durante uma década, além de ter travado amizade duradoura com os mais influentes proprietários escravistas desta itha e de Guadalupe. Por conseguinte, ambos os livros dialogaram diretamente com as
1. Seguindo o caminho aberto por Godelier, Ciro Flamarion Cardoso também ressaltou, mais recentemente (1988, p. 55), a necessidade de se "estudar os aspectos 'subjetivos' - ou seja, que envolvem concepçôes, idéias, conhecimentos, representações - das forças produtivas". 
práticas administrativas dos senhores de engenho das regiões para as quais se destinaram, e, assim procedendo, compartilharam da mesma racionalidade econômica desses proprietários.

É importante salientar que os textos de Antonil e de Labat foram muito utilizados pelos historiadores modernos para analisar a economia escravista brasileira e antilhana nos séculos XVII e XVIII. Na avaliação de Alice Canabrava, as obras de Antonil e de Labat são "os mais valiosos textos de toda a literatura histórica da primeira metade do século XVIII sobre a manufatura açucareira na América", e, pelo fato de terem sido escritas na primeira década do século XVIII, "permitem avaliar com bastante precisão o estado da técnica do preparo do açúcar nas Antilhas e no Brasil, naquela época" (CANABRAVA, 1981, pp. 13-14). Por isso mesmo, os dois textos serviram de base para a historiadora comparar as técnicas açucareiras brasileiras e caribenhas do século XVIII. Outra estudiosa que também recorreu ao cotejamento das duas obras foi Andrée Mansuy, na melhor edição crítica disponível do livro de Antonil (ANTONIL, 1968).

Entretanto, como Canabrava e Mansuy não estiveram preocupadas em examinar a forma pela qual Antonil e Labat apreenderam as técnica produtivas, elas não puderam perceber as profundas diferenças entre os dois relatos. Por serem os textos de Antonil e Labat os mais representativos da literatura açucareira coeva, eles é que constituirão a base documental desta análise. Efetuando-se uma comparação entre ambos, que tome em consideração o contexto do surgimento, os conceitos e categorias empregados, a organização formal do texto e o modo de tratamento das técnicas produtivas, será possível observar a diferença significativa da racionalidade econômica que presidiu a construção de cada um dos dois relatos.

Antonil

Em 1711, João Antônio Andreoni, um jesuita italiano que havia se estabelecido há longa data na Bahia, publicou em Lisboa, sob o pseudônimo de André João Antonil, o seu livro Cultura e Opulência do Brasil por suas drogas e minas. A obra dividia-se em quatro partes - Cultura e opulência do Brasil [1] na lavra do acúcar, [2] na lavra do tabaco, [3] pelas minas de ouro, e [4] pela abundância do gado e courama - cada qual cuidando respectivamente de um produto de vital importância econômica para a América portuguesa. A primeira parte da obra, sem dúvida a mais importante na acepção do autor, veiculava um tratado sistemático sobre a produção de açúcar tal como era praticada no Recôncavo baiano, mais particularmente no engenho. Sergipe do Conde, pertencente à Companhia de Jesus e reputado como "um dos mais afamados" da região.

No Proêmio da Cultura e Opulência do Brasil na lavra do açúcar, Antonil deixou expresso quais eram os seus dois grandes objetivos: em primeiro lugar, valorizar o açúcar por ser um produto de difícil fabrico, com maior importância para o Império luso do que as minas de ouro recém-descobertas no interior do Brasil; em seguida, servir como um guia de "notícias práticas" destinadas a auxiliar "quem de novo entrar na administração de algum engenho". Portanto, Antonil apresentou um objetivo mais amplo, que se reportava do 
conjunto da colônia, e um outro mais específico, o de oferecer um manual de administração para senhores de engenhos neófitos (ANTONIL, 1968, p.78). Para a consecução destes objetivos, o jesuíta italiano não apenas se limitou a descrever o padrão ideal de feitura do açúcar em todas as suas elapas num "engenho moente e corrente", como procurou igualmente traçar as normas que deveriam reger as relações entre o proprietário do engenho e todos os seus dependentes-lavradores de cana, família do senhor, capelão, feitores, mestre de açúcar, oficiais e escravos.

Por que somente no começo do século XVIII foi publicado em português um trabalho desta natureza? De início, pode-se afirmar que houve um descaso geral dos senhores brasileiros em relação ao tema: à noção arraigada entre os proprietários escravistas do século XVII e XVIII de que o conhecimento acerca da administração era adquirido somente com a prática, deve-se somar a própria exigüidade do público leitor colonial - a maioria dos proprietários escravistas brasileiros era iletrada. Não se trata de mero acaso o fato do jesuíta Andreoni ter sido o primeiro autor a escrever sobre o governo dos engenhos; afinal, os inacianos formaram o principal núcleo de letrados do Brasil colonial até a expulsão da Companhia de Jesus em meados do século XVIII.

Dentre as outras ordens religiosas européias com tentáćulos no Novo Mundo, os jesuítas se notabilizaram por pautarem sua ação de acordo com um projeto nitidamente missionário, imbuído do espírito da Contra-Reforma tridentina, sobretudo a partir do século XVII. Qualquer que fosse o objeto das atenções dos jesuítas no Brasil, o caráter missionário ficava por demais evidente: no caso das pregações para os colonos brancos do litoral, por exemplo, o que estava em jogo era levar a verdade de Cristo aos que corriam o risco de se afastar dela. Ao prescrever os padrões ideais de comportamento a serem observados pelos senhores no governo de seus engenhos, Antonil não se furtou em seguir as linhas clássicas do projeto missionário inaciano. Em todo o caso, a questão persiste: se os jesuítas estavam radicados nos principais núcleos coloniais brasileiros desde a metade dos quinhentos, e se eles próprios eram proprietários de engenhos de açúcar desde o início do século XVII, por que não trataram antes do tema da administração dos engenhos?

Para responder à pergunta, é fundamental que se entenda o contexto no qual foi produzida a obra de Antonil, vale dizer, a situação da economia e da sociedade escravista brasileira na passagem do século XVII para o XVIII. A questão essencial envolvida no governo de um engenho de açúcar colonial era a do comando de um grande contingente de trabalhadores escravos, especializados ou não. No final dos seiscentos, a escravidão africana já se encontrava consolidada no corpo social dos núcleos de povoamento da costa nordeste brasileira há pelo menos um século. Mas, a despeito de ser uma sociedade escravista estável, com hierarquias bem marcadas, tratava-se igualmente de uma sociedade permeada por inúmeras tensões. O foco principal destas tensões residia, sem sombra de dúvidas, nas relações entre senhores e escravos.

A instituição do cativeiro na costa nordeste brasileira foi, na segunda metade do século XVII, abalada pela erupção de diversas formas de resistência escrava, notadamente Palmares. Com efeito, o exemplo dos palmarinos inspirou um temor considerável nas autoridades escravistas luso-brasileiras do período. Em 
Pernambuco, por exemplo, este medo dos "holandeses de outra cor", nos dizeres de um governador colonial, desdobrou-se num pavor dos mocambos que se espalhavam por toda a mata canavieira, e que viviam da pilhagem dos lavradores e viajantes (MELLO, 1995, pp.92-93); além do mais, o episódio de Palmares trouxe também alterações relevantes na legislação lusa a respeito dos quilombos (LARA, 1996). Importa que, com o recrudescimento das diversas formas de resistência escrava na segunda metade do século XVII, a escravidäo africana foi alçada ao centro das atenções dos letrados coloniais, dos jesuítas principalmente, cujas reflexões passaram a se ocupar sistematicamente com a organização de projetos de controle social (VAINFAS, 1986, pp.84-87). É precisamente dentre tais projetos de normatização das relações sociais que se deve entender o livro de Antonil.

A Cultura e Opulência do Brasil na lavra do açúcar, no entanto, não se limitou apenas a procurar ordenar as relações entre senhores e escravos. Um outro tópico que muito atraiu as considerações de Antonil foi o dos vínculos existentes entre senhores de engenho e lavradores de cana. Ao contrário do que ocorreu nas Antilhas, grande parte da matéria-prima processada nos engenhos brasileiros era cultivada por proprietários escravistas que se encarregavam de abastecer as manufaturas com os feixes de cana. Não foi à toa que o autor se ocupou neste assunto justamente na passagem do século XVII para o XVIII. A economia açucareira brasileira, após trinta anos de crise provocada pela concorrência antilhana e pelo declínio dos preços do açúcar na Europa, voltava a vivenciar, a partir de 1690, uma conjuntura favorável, com a elevação dos preços pagos ao açúcar brasileiro em virtude das guerras coloniais européias (FERLINI, 1988, pp.70-84). A retomada dos antigos patamares produtivos trouxe o aumento das tensões entre senhores e lavradores, pois enquanto os primeiros preocupavam-se em garantir o fornecimento constante de matéria-prima, os últimos procuravam incrementar suas rendas reformulando os contratos com os senhores, ou mesmo buscando fundar os seus próprios engenhos (FERLINI, pp.211-215; SCHWARTZ, 1988, pp.247-2601.

A oscilação dos preços do açúcar na transição dos seiscentos para os setecentos lança luz igualmente sobre o porquê de Antonil ter se preocupado em fazer um relato minucioso sobre o modo de fabrico do produto, tal como praticado no engenho Sergipe do Conde. De fato, além de ser concebida como um conjunto de notícias práticas voltadas ao auxilio dos senhores de engenho neófitos, a Cultura e Opulência do Brasil na lavra do açúcar, segundo as palavras do seu Proêmio, também pretendia expôr a complexidade da feitura do produto aos "que não sabem o que custa a doçura do açúcar a quem o lavra", e assim, "o conheçam, e sintam menos dar por ele o preço que vale" (ANTONIL, 1968, p.781. Em outras palavras, calcada na idéia de justo preço da escolástica, a obra trazia outrossim o propósito de valorizar o açúcar como um gênero de difícil fabrico, portanto merecedor de melhores cuidados da Coroa portuguesa.

Em resumo, os problemas que mais prenderam a atenção de Antonil na parte de sua obra referente ao açúcar foram, em primeiro lugar, a normatização das relações entre os diversos grupos que constituíam o universo dos engenhos brasileiros - senhores de engenho, lavradores de cana, capelães, feitores, mestres de açúcar, oficiais e escravos - e, em segundo lugar, a descrição 
dos procedimentos corretos de feitura do açúcar. $\bigcirc$ tratado de Antonil sobre a administração dos engenhos, por conseguinte, tinha uma intenção eminentemente normatizadora, bem de acordo com o projeto jesútico de guiar a cristandade colonial, ao prescrever o comportamento ideal do senhor de engenho no governo de sua propriedade; neste sentido, como bem assinalou a historiadora Alice Canabrava, o escrito se configurava basicamente como uma obra de ética (CANABRAVA, 1967, pp.43-44).

Como tal, a obra de Antonil não poderia deixar de recorrer aos esquemas intelectuais fornecidos pela literatura clássica sobre o governo da casa. As convençōes intelectuais às quais recorreu Antonil remontam, por um lado, aos escritos de Xenofonte e da escola aristotélica sobre a oikonomia, isto é, sobre o governo da casa, e, por outro, aos manuais latinos de Całão, Varrão e Columella. Isto fica evidente ao se efetuar uma leitura em separado de cada um dos três livros que compõem a Cultura e Opulência do Brasil na lavra do açúcar. O Livro I inicia-se com um capítulo sobre o cabedal necessário a um senhor de engenho, e um outro sobre a compra e arrendamento das terras para a lavoura açucareira. Os capífulos restantes cuidam exclusivamente das relações entre o senhor de engenho e os diversos dependentes, relações estas que observam uma nítida gradação hierárquica, já que, nas palavras do autor, a "boa disposição e governo" do engenho implicam na "eleição dos feitores e oficiais, na boa correpondência com os lavradores, no trato da gente sujeita, na conservação e lavoura das terras que possui, e na verdade e pontualidade com os mercadores e outros seus correspondentes na praça" (ANTONIL, 1968, p.90). A filiação à literatura grega sobre o governo da casa é inegável. Basta tomar o exemplo dos Oikonomika, arribuídos durante muito tempo a Aristóteles, sendo em realidade um tratado à moda aristotélica que se baseou tanto no livro I da Política de Aristóteles como no Oikonomikos de Xenofonte: o Livro I dos Oikonomika se ocupa em definir as funções do governo da casa, em precisar os papéis a serem cumpridos pelo esposo e pela esposa nesta faina, e em normatizar as relaçōes entre escravos e senhores (PSEUDO-ARISTÓTELES, 1984). Guardadas as devidas proporções, trata-se do mesmo tipo de preocupação e de construção formal que seriam empregados no Livro I da obra de Antonil. Por outro lado, os Livros II e III da Cultura e Opulência do Brasil na lavra do açúcar, ao trazerem uma descrição pormenorizada de todas as etapas de feitura do açúcar, do número de trabalhadores requeridos em cada uma delas, dos tipos de operação envolvidos e das ferramentas utilizadas, prendem-se - como Andrée Mansuy indicou - à tradição dos manuais romanos de agricultura.

O tema das técnicas produtivas empregadas nos engenhos brasileiros, portanto, foi tratado de forma sistemática por Antonil nos Livros II e III. O princípio que ordenou a seqüência do tratamento do assunto foi o próprio fluxo do processo produtivo do açúcar. Assim, o primeiro assunto abordado foi o da escolha das terras para o plantio da cana de açúcar, pois "as terras boas ou más são o fundamento principal para ter um engenho real bom ou mau rendimento". Os solos mais adequados ao plantio da cana seriam os de massapé ; de qualidade inferior eram os salões, "terra vermelha de poucos cortes porque logo enfraquece"; por último, haviam as terras areíscas, "uma mistura de areia e salões", que serviam apenas ao plantio de mandiocas e legumes, mas não para 
- de cana (ANTONIL, 1968, p. 148). Feita a opção pelas terras mais apropriadas, procedia-se ao plantio, que, nos outeiros, ocorria entre o final de fevereiro e o final de maio; nas terras baixas e nas várzeas, o plantio poderia prosseguir nos meses de jutho e agosto. O local onde era plantada a cana também determinava a quantidade de limpas anuais que seriam necessárias; os canaviais das terras altas, por serem menos úmidos, exigiriam uma quantidade menor de mondas do que os das várzeas. Aliás, o capim era "o inimigo mais molesto e mais contínuo" da cana, o que levava os senhores a obrigarem seus escravos a mondar constantemente os canaviais (pp. 154-8).

A cana, para estar no ponto ideal de corte, deveria passar por um tempo de crescimento e maturação de dezessete a dezoito meses. Como o período da safra durava entre oito e nove meses, Antonil recomendava aos senhores e lavradores o escalonamento do plantio. "A advertência do bom lavrador", ressaltou o jesuíta, "consiste em plantar de tal sorte sucessivamente a cana que cortando-se a velha para a moenda, fique a nova em pé para a safra vindoura, e desta sorte alimente com a sua verdura a esperança do rendimento que se prepara, que é o prêmio do seu continuado trabalho" (p. 156). Chegado o início da safra, o senhor de engenho estabeleceria o cronograma de moagem, avisando aos lavradores quais eram os dias reservados ao processamento da matéria-prima deles. $O$ cronograma deveria ser rigorosamente observado, pois as canas, tão-logo cortadas, precisavam ser moídas no máximo em vinte e quatro horas, caso contrário perderiam a capacidade de render bom açúcar (pp. 160-2).

Em relação à colheita da cana, Antonil se preocupou em precisar a forma como era organizado o Irabalho nesta faina. Os escravos eram divididos em duplas, normalmente composta por um escravo e uma escrava; cada dupla tinha uma cola diária pré-determinada de cana a cortar (no sistema de contagem adotado nos engenhos brasileiros, por volta de 4200 canas amarradas em feixes de dozel; caso terminasse a tarefa estipulada antes do final da jornada, a dupla teria o restante do dia ao seu dispor. Nas outras fainas do engenho, que não obedeciam a um sistema de tarefas, o trabalho organizava-se de um modo algo diferente: a jornada era de sol a sol, e se caracterizava como uma labuta coletiva dos escravos (pp. 162-164).

Após o corte, as canas amarradas em feixes eram transportadas para a casa do engenho, onde se dava a extração do caldo. Neste momento da narrativa, baseando-se no exame que realizou no engenho Sergipe do Conde, Antonil fez uma descrição minuciosa do "artifício de eixos e rodas" que compunha a moenda, e, na seqüência, tratou do modo correto a ser empregado no processo de moagem. As canas, limpas da palha e da lama, eram passadas duas vezes pelos eixos verticais da moenda, para que fosse extraída a maior quantidade possível de sumo. De acordo com Antonil,

\footnotetext{
"no espaço de vinte e quatro horas mói-se uma tarefa redonda de vinte e cinco até trinta carros de cana, e em uma semana das que chamão solteiras (que vem a ser sem dia santol chegam a moer sete tarefas; e o rendimento competente é uma forma ou pão de açúcar por fouce, a saber quanto corta um negro em um dia. Nem o fazer mais açúcar depende de moer mais cana, mas de ser a cana de bom rendimento, a saber bem açucarada, não aguacenta nem velha. Se meterem mais cana ou bagaço do que convém, haverá risco de se quebrar o rodete, e a moenda dará de si e rangerá na parte de cima, e poderá ser que quebre algum aguilhão. Se a água que move a roda
} 
for muita, moerá tanta cana que não poderá dar vazão na casa das caldeiras, e o caldo azedará no parol de coar por não se poder cozer em tanta quantidade nem tão depressa nas tachas" (pp. 182-184).

Antonil deixava expresso neste trecho que o rendimento do engenho repousava na quantidade de sumo que continham as canas; por este motivo, o escalonamento do plantio era fundamental ao rendimento do engenho, ao garantir que os feixes só fossem para a moagem no ponto certo de maturação. Por essa mesma razão, de pouco adiantava tentar moer mais feixes do que comportava a moenda, ou então acelerar a rotação da roda d'água para extrair mais sumo: no primeiro caso, a engrenagem correria o risco de quebrar; no segundo, a casa das caldeiras não teria como processar todo o caldo extraído. o "bom governo da moenda" pelo feitor deste espaço significava exatamente manter a moagem no ritmo adequado à vazão da casa das caldeiras.

À extração do caldo seguia-se a etapa de cozimento na casa das caldeiras. Antes de apresentar as operações desempenhadas neste espaço, Antonil fez uma descrição das fornalhas que aqueciam as caldeiras, dos tipos de lenha requeridos para gerar diferentes intensidades de fogo, e dos escravos envolvidos nesses trabalhos. O tópico sobre a construção das fornalhas teve uma atenção especial, pois a garantia de um calor intenso era basilar para que o processo de cozimento fosse efetuado corretamente:

\begin{abstract}
"nos engenhos reais, costuma haver seis fornalhas e nelas outros tantos escravos assistentes, que chamam metedores da lenha. As bocas das fornathas são cercadas com arcos de ferro, não só para que sustentem melhor os tijolos, mas para que os metedores, no meter da lenha, não padeçam algum desastre. Tem cada fornalha sobre a boca dois bueiros, que são como duas ventas, por onde o fogo resfolega. Os pilares que se levantam entre uma e outra, hão de ser muito fortes, de tijolo e cal, mas o corpo das fornalhas faz-se de tijolo com barro, para resistir melhor à veemente atividade do fogo, ao qual não resistiria nem a cal, nem a pedra mais dura; e as que servem para as caldeiras são alguma cousa maiores que as que servem para as tachas" (op.cit., pp. 198-2001
\end{abstract}

Ao cuidar da casa das caldeiras, Antonil descreveu em detalhes os aparelhos e os utensílios que eram aí requeridos, e as funções de cada um de seus trabalhadores - o mestre do açúcar, seu auxiliar imediato, o banqueiro, e os caldeireiros e tacheiros. Sobre a importância do mestre do açúcar para o engenho, advertiu Antonil: "da inteligência de um e de outro [i.e., do mestre e do banqueiro] depende em grande parte o fazer-se bom ou mau açúcar. Porque ainda que a cana não seja qual deve ser, muito pode ajudar a arte no que faltou a natureza. E pelo contrário, pouco importa que a cana seja boa se o fruto dela e o trabalho de tanto custo se botar a perder por descuido (...)" Por conseguinte, se a quantidade de açúcar a ser produzida no engenho dependia da cana ser "bem açucarada", a qualidade do açúcar escorava-se em larga medida na habilidade do mestre e do banqueiro. Acerca das operações dos escravos sob o comando do mestre de açúcar, de forma semelhante ao que ocorria com os escravos do eito no corte da cana, também o trabalho de caldeireiros e tacheiros era regulado por um sistema de tarefas. A cota diária dos primeiros era processar três caldeiras e meia de caldo; a dos últimos, a quantidade necessária para preencher ao término da jornada de quatro a cinco formas de melado (p.210). 
Terminado o cozimento do caldo, nesta altura já convertido num melado purificado e concentrado, havia a exigência de preparáto previamente antes de passá-lo às fôrmas para dar início à purgação. Feito isso e preenchidas as fôrmas, estas eram transportadas para a casa de purgar, o maior edifício de todo o complexo do engenho. Também na etapa da purgação era preciso um cuidado especial. Para ser de boa qualidade e rendimento, vale dizer, para que produzisse uma alta proporção de açúcar alvo em relação ao mascavo, a ação da umidade da argila disposta nos tampos das fôrmas deveria ser bem vagarosa, o que dependia por sua vez da qualidade da cana e do correto cozimento. Finda a purgação em pouco mais de um mês, o processo produtivo terminava com a retirada dos pães de açúcar das fôrmas, e com as ações de separar o açúcar branco do mascavo, de secar ao sol e de encaixar as diferentes castas do produto (pp. 254-262).

Para os efeitos da presente análise, importa que, ao procurar fixar os processos ideais de fabrico do açúcar, Antonil acabou por realizar uma descrição estática das técnicas produtivas, sem deixar espaço para soluções alternativas. Em nenhum momento da Cultura e Opulência do Brasil na lavra do açúcar o seu autor aventou a hipótese de existirem outras técnicas que não as descritas no texto. Aliás, este foi exatamente o ponto criticado pelo reformador ilustrado Frei José Mariano da Conceição Velloso, na edição a seu cargo da obra de Antonil publicada em 1800. Segundo Velloso, quando o jesuíta italiano

\begin{abstract}
"escreve acerca da extração deste precioso sal essencial é mais devido aos othos que ao seu entendimento; pois só escreve o que vira fazer nos mais célebres engenhos da Bahia, sem avançar o que deveriam fazer, isto é, coisa alguma sobre o seu melhoramento, ou no todo, ou nas partes que o constituem, quero dizer, suavizar o enorme peso das suas máquinas, diminuir o imenso consumo de suas lenhas, methorar - químico processo da extração desse sal essencial, assim na quantidade, como na qualidade" (VELLOSO, 1800).
\end{abstract}

Isto não significa afirmar que os processos produtivos relatados na Cultura e Opulência do Brasil na lavra do açúcar fossem atrasados em relação ao nivel técnico vigente na agromanufatura açucareira do período; muito pelo contrário, pois os processos descritos por Antonil haviam trazido para o açúcar brasileiro uma excelente reputação no mercado europeu da segunda metade do século XVII.

A descrição estática das técnicas produtivas dos engenhos brasileiros, contudo, não foi algo decorrente do próprio sucesso de sua produção. O descaso de Antonil em relação às eventuais técnicas alternativas de produção do açúcar se justifica pelo escopo da sua obra e pela racionalidade econômica que a governou. O foco de suas atenções era o poder senhorial, o comportamento ético dos senhores no comando de seus engenhos, e não o incremento lécnico da produção de açúcar. Por conseguinte, foi exatamente essa racionalidade que - impediu de conceber técnicas alternativas para o processo produtivo dos engenhos brasileiros.

Labat

Em 1722, onze anos portanto após a publicação do livro de Antonil, veio a lume em Paris, em seis volumes in-duodecimo, a obra Nouveau Voyage 
aux Isles de l'Amerique, da autoria do padre dominicano francês Jean Baptiste Labat. O próprio título da obra indicava qual era o campo no qual ela se inscrevia, a saber, os relatos de viagem à América que tratavam de uma grande variedade de assuntos. As palavras iniciais do Prefácio do livro não deixavam margens para dúvidas:

"Les Memoires que je donne au Public, ne sont autre chose que la Relation \& le Journal du voyage \& du sejour que j'ai fait aux Isles de l'Amerique pendant environ douze années. Les differens emplois que i'y ai eus, ont fecondé mon inclination naturelle, \& m'ont acquis une connoissance trèsétenduë \& très-particuliere de tous ces Païs. On le verra par le détail dans lequel je suis entré, tant des Arbres, des Plantes, des Fruits, des Animaux, que des Manufactures qui y sont établies \& qu'on y pourroit établir. J'ai traité assez amplement des établissements des Colonies qui y sont à present, des Guerres qu'elles ont eu à soûtenir contre les Naturels du Païs \& contre les Etrangers qui les on attaquées; de l'origine des Sauvages, de leur Religion \& de leurs Coûtumes; (...). (LABAT, 1722, v.l, pp.vii-viii).

Na verdade, existiam algumas narrativas semelhantes disponiveis aos leitores do período, como o próprio Labat reconhecia; o seu objetivo, no entanto, era o de fornecer informaçōes mais atualizadas sobre as ilhas, suplantando dessa forma as lacunas - ou até mesmo os erros - dos relatos anteriores.

Para comprovar a importância da sua narrativa de viagem, Labat dedicou quase todo o Prefácio à realização de um balanço da literatura existente sobre as Antilhas francesas. Assim, ao relato do também dominicano Du Tertre, publicado em 1658, Labat reservou os maiores elogios. Contudo, como a obra de Du Tertre foi composta nos primeiros anos da colonização francesa no Caribe, uma série de informações importantes não foram registradas, em especial as referentes às "produções da natureza"; dos produtos que, em 1722, constituiam a riqueza da região, a única descrita com precisão por Du Tertre foi a lavoura do tabaco (op.cit., pp.ix-x). Se Labat foi complacente na apreciação do relato de seu companheiro dominicano, o mesmo não se pode afirmar acerca dos seus juízos sobre as obras de Biet, Rochefort e Durret. A primeira, a Histoire de la France Equinoxiale, de 1664, não apresentava dados relevantes, pois Biet não observou diretamente grande parte do que registrou sobre as colônias francesas na América, baseando-se tão-somente nas informações de outros viajantes. $\bigcirc$ segundo autor, Rochefort, não passou de um plagiador da pior espécie da obra de Du Tertre, já que alterou uma série de informações corretas que eram fornecidas pelo último. Por fim, as maiores críticas ficaram reservadas para Durret: a Voyage de Marseille à Lima, publicada em 1720, era uma espécie de síntese dos relatos extensos sobre viagens à América redigidos por autores que nunca botaram os pés no Novo Mundo (pp.x-xxiii).

A despeito de todas as críticas, não há como negar a filiação de Labat a este tipo de narrativa de viagem. Afinal, a tradição de relatos que cuidavam da história natural e moral das Antilhas se encontrava solidamente estabelecida entre franceses e ingleses desde meados do século XVII. De acordo com James McClellan, que examinou a variante francesa dessa literatura, a história dos relatos sobre as Antilhas relaciona-se intimamente com a história do próprio colonialismo francês nas Índias Ocidentais: com objetivos variados, os autores desses textos - quase sempre missionários religiosos - procuraram por meio 
de seus escritos catequizar as comunidades coloniais, informar os metropolitanos sobre a experiência colonial com vistas à sua popularização na França, ou mesmo municiar a comunidade científica francesa com informações sobre a história natural do Novo Mundo (MCCLELLAN, 1992, p. 111 ).

Sabendo-se que a Nouveau Voyage aux Isles de l'Amerique fez parte de uma sólida tradição intelectual, há que se lembrar em quais elementos seu autor escorou o sentimento de superioridade sobre os escritos que o precederam. Labat tinha um profundo conhecimento sobre as ilhas da Martinica e de Guadalupe, pois havia vivido nelas por doze anos. Tendo sido administrador dos engenhos de açúcar dos dominicanos na Martinica, ele também pôde escrever com conhecimento de causa sobre a produção agrícola das ithas. Além do mais, - período compreendido por sua narrativa, de 1694 a 1705, representa um momento no qual a economia escravista da Martinica e Guadalupe - em especial a produção açucareira - se encontrava estabelecida sobre bases sólidas (SCHNAKENBÓURG, 1968; DEERR, 1949, v.l, pp.233-234). Dentro deste quadro é que se deve entender a redação da obra de Labat, que traz informações minuciosas sobre a produção francesa de açúcar, tabaco, anil, algodão e outros gêneros, e que só se tornou possivel no contexto da passagem do século XVII para o XVIII.

Antes de analisar o tratamento dado por Labat às técnicas produtivas empregadas nos engenhos de açúcar caribenhos, cabem algumas palavras sobre a organização formal do livro. Pelo fato de ter sido editada in-duodecimo lum tipo de edição que tornava o livro mais barato, com maiores possibilidades de circulaçãol, o conjunto dos seis volumes da obra ficou com mais de 3000 páginas. A forma escolhida para a exposição foi a de um diário de viagem. Composto desta forma, torna-se evidente que o livro pretendia cativar o leitor, aproximando-o dos elementos pitorescos presentes numa viagem aos trópicos. 0 encadeamento dos assuntos registrados obedeceu à seqüência cronológica da observação de Labat sobre as Antilhas. Quando os assuntos descritos mereceram "une explication longue \& un ample détail", Labat interrompeu o fluxo da narrativa para abordá-los sistematicamente. Assim, no livro estão presentes desde capítulos reservados exclusivamente à história natural das ithas até verdadeiros tratados agronômicos sobre as plantas de maior relevância econômica para a metrópole.

De acordo com tal lógica expositiva, Labat dedicou praticamente todo o terceiro tomo da Nouveau Voyage aux Isles de l'Amerique à produção de açúcar. Como na Cultura e Opulência do Brasil na lavra do açúcar, a exposição foi organizada conforme o próprio processo produtivo, o que facilita em muito a comparação das duas obras. Contudo, antes de qualquer coisa, é importante anotar uma diferença significativa entre o livro de Antonil e o de Labat. Trata-se da presença de pranchas no livro do dominicano francês e a sua ausência no do jesuíta italiano. Como se verá mais adiante, as gravuras desempenham um papel fundamental na narrativa de Labat. A função delas ultrapassa em muito o papel de mero complemento visual ao texto: as pranchas informam tanto quanto o texto, o que é um indicativo da preocupação de Labat com a precisão técnica.

Cabe agora comparar as diferentes formas de abordagem das técnicas produtivas no texto de Labat e no de Antonil. Sobre a etapa agrícola da feitura do açúcar, Labat - assim como Antonil - reconheceu que a determinação da 
quantidade de açúcar que poderia ser obtida numa safra repousava, em última instância, na qualidade do sumo da cana, vale dizer, um caldo com pouca água e muito açúcar. A qualidade do caldo, por sua vez, vinculava-se a quatro fatores: a qualidade do terreno, a exposição das canas ao sol, a época do ano em que se realizaria o corte (estação chuvosa ou seca) e a idade da cana (LABAT, 1722, v.lll, pp. 13 1-132). Se em relação à avaliação do que influia na produção de uma boa cana não houve diferenças entre Antonil e Labat, no que se refere ao método de plantio e de organização do canavial existiu uma profunda distinção entre ambos. Labat recomendou que, estando o terreno bem limpo de ervas daninhas e tocos, os canaviais fossem divididos em quadrados com cem passos de lado cada, entremeados por caminhos de dezoito pés de largo (pp. 141-142).

Quais eram as vantagens do plantio regular em quadrados sobre 0 método irregular que vigorava, por exemplo, no Brasil? Além de embelezar a propriedade, a divisão dos canaviais em quadrados impediria a propagação do fogo de um quadrado ao outro quando ocorressem incêndios; impediria, também, que na época da safra os carros de bois passassem por cima dos rebentos das canas cortadas; no período de crescimento das canas, os caminhos entre os quadrados poderiam ser aproveitados para o cultivo de mantimentos; mais importante que tudo, no entanto, era a facilidade fornecida por este método para o controle do trabalho escravo:

"le maitre peut plus facilement visiter le travail de ses gens, \& voir si les Commandeurs \& les Negres ne le trompent point, comme ils ne manquent gueres de faire, quando ils en trouvent l'occasion, se contentant de sacler \& de rechausser les cannes qui sont sur les bords des chemins, pendant que le milieu où la vüê ne peut penetrer \& où l'on ne peut pas aller, demeure negligé, plein d'herbes, de liannes \& de vuides, ce qui attire avec le tems le dépérissement total des connes" (LABAT, 1722, v.lll, p. 143)

À divisão do canavial em quadrados somava-se o plantio alinhado das canas como um instrumento que aumentaria o controle sobre o trabalho escravo, tanto nas capinas do canavial quanto na época do corte da cana. Aliás, a preocupação com a supervisão estrita dos escravos no campo, ao menos no período da safra, foi algo ausente do tratado de Antonil. Isto se explica pelas diferentes formas de organização do trabalho adotadas nos engenhos brasileiros e nos antilhanos. Como se viu, no Brasil o sistema de trabalho empregado na safra permitia que os escravos, assim que tivessem cumprido a cota prédeterminada de canas a serem cortadas na jornada, desfrutassem o restante do tempo ao próprio dispor. Nas Antilhas, pelo contrário, não havia esta margem de autonomia para os escravos: o trabalho era realizado coletivamente sob o comando unificado do feitor, e a quantidade de cana a ser cortada em cada dia variava conforme o ritmo de processamento do caldo na fábrica (pp. 171-175).

A respeito da moagem da cana, Labat demonstrou uma preocupação muito maior do que Antonil em descrever o funcionamento dos mecanismos de extração do caldo. Além do mais, foram apresentados quatro tipos distintos de moenda, sendo que todas as descrições se fizeram acompanhar por estampas que forneciam detalhes técnicos sobre as partes componentes das moendas (Ver anexo de imagens). Para cada uma das moendas, Labat fez um balanço de suas vantagens e desvantagens, levando em consideração aspectos como a 
composição dos materiais necessários à construção, a durabilidade das engrenagens, a facilidade de manuseio, os custos de manutenção e a capacidade de moagem. Numa alitude que explicita a sua inquietação com o incremento técnico da manufatura, Labat incluiu no texto um projeto alternativo de sua autoria para a construção de uma nova moenda hidráulica, cujas vantagens estariam no aumento da velocidade que seria transmitida aos tambores, na redução dos custos de construção e na facilidade de controlar a água. Entretanto, Labat não foi conclusivo quanto aos benefícios dessa moenda, pois, por conta de sua volta à França em 1705, ela não pôde ser efetivamente testada (pp. 176-255).

Ainda no item referente às moendas, foi apresentada mais uma inovação técnica desconhecida no Brasil, a saber, o uso do bagaço da cana como combustivel para as fornalhas (pp.202-205). É certo que Labat pontou que apenas nas regiões onde não havia mais lenha disponível para queimar se recorreu ao emprego do bagaço; tal foi o caso das terras baixas da Martinica e Guadalupe, de toda a itha de Saint Christophle (parte francesa e inglesa) e de Barbados. Nas regiōes onde havia reservas florestais disponiveis, continuou-se a utilizar lenha. Conseqüentemente, não cabe falar aqui de atitude intelectual próinovação, pois se trata de uma evidente adaptação. das técnicas manufatureiras às constrições do meio geográfico.

Sobre as fornalhas, pode-se afirmar que Labat descreveu um padrão técnico análogo ao vigente no Brasil; as recomendações traçadas para a construção das fornalhas não diferiram muito das prescritas por Antonil. Contudo, e nisto reside o cerne da sua atitude intelectual pró-inovação técnica, Labat registrou a existência de uma fornalha alternativa. Nas suas palavras,

"depuis mon départ des Isles on a mis en usage une espece de forneau qui chauffe bien, \& qui consomme peu de bois. Je n'ay pas vî ces nouveaux forneaux, \& ceux qui m'en ont parlé, n'ont pú m'en donner une idée assez distincte pour en faire ici la description" (p.272)

Portanto, como não chegou a conhecer esta fornalha e as descrições que the foram feitas não bastaram para the dar uma idéia precisa sobre como era o novo tipo de forno, Labat deixou de fornecer as instruções para a construção do novo equipamento. Não obstante, o dominicano manteve o caminho aberto, visto que reconheceu a relevância da inovação para a agromanufatura açucareira. Como se verá mais adiante, em seus escritos posteriores esta foi uma das lacunas preenchidas por Labat.

Ao cuidar da etapa do cozimento do caldo na casa das caldeiras, Labat descreveu com vagar o espaço interno desta oficina e os instrumentos aí utilizados. As estampas que acompanham o item são de vital importância para o entendimento não só da lógica arquitetônica desse espaço, mas igualmente para a visualização dos diversos utenślios necessários aos trabalhos dos escravos (pp.255-280). Entretanto, para se fazer açúcar de boa qualidade era indispensável o controle do processo por um bom mestre de açúcar. Como os caldos obtidos das canas eram de diferentes qualidades, uns mais aguados e outros menos, o grau de cozimento nunca poderia ser o mesmo. "Toute la science des Rafineurs", nos dizeres de Labat, consistia em saber avaliar corretamente qual era o ponto correto de cozimento do caldo em cada uma das caldeiras, para 
que, no final do processo, o açúcar obtido fosse de excelente qualidade lpo.284 286). Como se percebe, a avaliação de Labat sobre esta questão escorou-se em princípios análogos aos de Antonil.

mesmo não se pode afirmar acerca da produção das diferentes espécies de açúcar. Enquanto Antonil centrou sua descrição apenas na feitura do açúcar branco purgado, trazendo umas poucas considerações adicionais sobre os preços dos açúcares obtidos como subprodutos do processo de feitura do açúcar branco, Labat procurou descrever em detalhes os processos empregados na obtenção de dez espécies diferentes de açúcar (pp.297-394). O que mais nos interessa nessa forma de abordagem adotada pelo dominicano francês é a comparação que ele estabeleceu entre os ganhos granjeados com a produção do açúcar branco purgado e os obtidos com a produção de açúcar bruto. Segundo Labat, a opção pela produção de um ou de outro tipo de açúcar deveria levar em conta as forças do mercado e a contabilidade interna da propriedade. $\bigcirc$ autor chegou à conclusão de que era mais vantajosa do ponto de vista econômico a produção de açúcar branco purgado pronto para ser consumido, ou seja, sem a necessidade de nenhum beneficiamento posterior (pp.400-403).

Ora, o processo de preparo do açúcar para a comercialização prescrito por Labat é o mesmo que foi anotado como o ideal por Antonil. A opção de Labat, porém, escorou-se num cálculo contábil explícito, que aventou a possibilidade alternativa de se produzir açúcar bruto, ao passo que em Antonil o único caminho sugerido foi o da produção de açúcar branco purgado. Portanto, temos aqui, uma vez mais, duas atitudes intelectuais substancialmente distintas frente ao processo produtivo açucareiro.

Esta clivagem fica muito clara no último parágrafo do capítulo sobre o açúcar da Nouveau Voyage aux Isles de l'Amerique. Nos termos de Labat,

"ceux qui auront acquis plus de lumieres que moi, obligeront le Public de me les communiquer, afin que je lui en fasse dans une seconde Edition de ces Memoires, s'il y en a une, dans laquelle je ne manquerai pas de faire connoitre à qui on sera redevable de ce qui je dirai de nouveau" $\mid$ p.464)

Este parágrafo expressa uma espécie de síntese da atitude intelectual de labat frente às técnicas produtivas açucareiras. Ao abrir a possibilidade de modificar o texto em edições posteriores para incorporar novos dados sobre a indústria do açúcar nas Antilhas, em especial as informações sobre novas técnicas produtivas que porventura pudessem surgir na região, Labat explicitou qual foi a racionalidade econômica que conformou o substrato do seu livro: a busca sistemática do incremento técnico dos engenhos de açúcar pertencentes aos franceses no Caribe.

A Nouveau Voyage aux Isles de l'Amerique do Padre Labat pode ser considerada, sem exageros, a obra fundadora da literatura açucareira caribenha do século XVIII. A forma de abordar a agromanufatura do açúcar nas Antilhas e a busca sistemática por inovações técnicas encontraram uma série de desdobramentos em outros textos ao longo dos setecentos. 
O peso da obra de Labat durante o século XVIII pode ser aferido por diversos indicativos. De início, vale lembrar o sucesso editorial obtido pelo livro na Europa. À edição in-duodecimo com seis volumes de 1722 seguiu-se, dois anos depois, uma reimpressão em dois volumes in-quarto, editada em Haia. Em Amsterdã também foi impressa uma tiragem em 1725. Em Paris, publicou-se novamente a obra em 1738, ano da morte de Labat, e em 1742; estas duas edições trouxeram diversas modificaçōes feitas pelo próprio autor. Há ainda uma outra impressão feita em 1738 em Haia, isto sem contar as traduções que foram feitas para outras línguas. Essas diversas edições transformaram o relato de Labat - segundo observação de Russell Jameson - numa das principais fontes de informação sobre as Antilhas francesas disponíveis para os ilustrados franceses do século XVIII (JAMESON, 1971, pp.191-192).

A obra de labat teve grande repercussão também entre os ingleses. Como o historiador cubano Manuel Moreno Fraginals indicou, a cartilha The art of making sugar, publicada em Londres em 1752, "foi praticamente copiada do capítulo do Padre Labat sobre o açúcar" (FRAGINALS, 1987, v.l, p.88). Aliás, até a publicação do livro de Samuel Martin na década de 1760, essa cartilha foi um dos poucos manuais disponiveis em língua inglesa sobre a produção de açúcar nas Antilhas (SHERIDAN, 1960).

Mais importantes, no entanto, foram os desdobramentos verificados em outros textos franceses sobre a produção açucareira publicados até o último quarto do século XVIII. Em primeiro lugar, os textos posteriores do próprio Labat seguiram a linha por ele aberta em 1722. O dominicano, depois de seu regresso à França em 1705, nunca mais viajou às regiões coloniais francesas. Não obstante, escorado no sucesso editorial de seu livro de 1722, ele passou a copilar relatos de viagem de outros autores, em especial os que tratavam da descrição do litoral africano. Baseado em tais relatos, em 1728 Labat publicou uma Nouvelle Relation de l'Afrique occidentale, e, em 1730, a Voyage du Chevalier des Marchais en Guinée, Isles Voisines, et a Cayenne, fait en 1725, $1726 \& 1727$.

Na passagem em que cuidou da descrição da produção açucareira da colônia francesa de Caiena, o relato publicado em 1730 trouxe um complemento fundamental à Nouveau Voyage aux Isles de l'Amerique. Atendendo aos apelos de Labat feitos em 1722, seus amigos residentes na Martinica (todos senhores ou administradores de engenhol the enviaram "les desseins des nouveaux forneaux des sucreries, inventées para les Anglois pour diminuer la consommation prodigieuse de bois que se faisoit dans les anciens fourneaux", desenhos estes que se fizeram acompanhar pelas respectivas explicações escritas. Ora, como os novos fornos (denominados pelos colonos de "forno ingles" ") haviam sido implantados rapidamente nos engenhos da Martinica após 1705, por conta da "comodidade infinita" deles, da enorme economia de lenhas que eles representavam e do perfeito cozimento propiciado, Labat não teve dúvidas em publicar as informações sobre a novidade na Voyage du Chevalier des Marchais... (LABAT, 1730, v. 3, p. 232). Como se pode perceber, temos aqui uma demonstração evidente dos vínculos estreitos que uniram os textos de Labat $e$ as práticas administrativas empregadas nos engenhos antilhanos. 
Cabe comparar em poucas linhas as estampas que difundiram a novidade técnica em $1730 \mathrm{com}$ as pranchas sobre a casa das caldeiras que constavam da edição de 1722. Nas últimas, estão presentes dois desenhos. $\bigcirc$ primeiro é um corte vertical da casa das caldeiras, no qual é possivel notar a posição dos fornos embaixo das caldeiras, o alpendre externo onde se ocalizavam as bocas dos fornos, e a articulação do espaço do terno das caldeiras com o local destinado ao preenchimento das barricas com açúcar bruto e à preparação das formas de barro antes de passá-las à purgação. O segundo desenho é uma planta baixa do edificio, com a identificação de cada uma das caldeiras e do espaço reservado às formas e barricas. Não há, portanto, nenhuma representação visual voltada especificamente para a construção das fornalhas. É exatamente esta a lacuna preenchida pelo livro de 1730, que exibe três gravuras. A primeira traz uma visão frontal exierna da casa das caldeiras, com as aberturas do forno inglês e a chaminé: a boca do forno, onde se faz o fogo, encontra-se à direita; à esquerda, têm-se pequenas bocas, localizadas embaixo de cada uma das caldeiras, que servem para a retirada das cinzas. A segunda gravura é uma planta baixa do terno de caldeiras, na qual é possivel observar o interior das fornalhas e o canal condutor das chamas e do calor. A terceira gravura também é uma planta baixa, agora com a idéntificação da ordem das caldeiras sobre o forno inglês. Nas gravuras de 1730, por conseguinte, há uma nítida preocupação com a visualização da exata construção dos fornos; a descrição verbal complementar às imagens se encarrega de fornecer as informações necessárias sobre o diâmetro das fornalhas, sobre as dimensões das aberturas localizadas embaixo de cada caldeira para a retirada das cinzas e sobre o canal condutor do fogo.

Um outro indicativo importante do peso da obra de Labat no decorrer dos setecentos foi a sua transformação em referência sobre a produção de açúcar para as enciclopédias do século XVIII. Os irmãos Savary des Bruslons, no Dictionnaire Universel de Commerce publicado originalmente entre 1723 e 1730, valeram-se da Nouveau Voyage aux Isles de l'Amerique como a principal fonte de informações para a composição do artigo sobre o açúcar (SAVARY DES BRUSLONS, 1741, 1.3, pp.224-2451. Não custa ressaltar que o Dictionnaire dos Savary teve uma ampla circulação por toda a Europa durante o século XVIII (PERROT, 1992, pp.101-104).

mesmo processo se fez presente na composição dos artigos sobre - acuúcar na Encyclopédie editada por Diderot e D'Alembert. Os artigos em questão foram redigidos por $M$. de La Romain, responsável geral pelos temas referentes à "História Natural das lihas da América", e se encontram no tomo XV, em 1765; três anos antes, já haviam sido impressas as pranchas relativas à produção de açúcar. A base para a composição dos artigos e das gravuras foi fornecida pelos relatos de Labat. Se as informações contidas nos artigos de Romain se limitaram a resumir os dados fornecidos pelo dominicano, as estampas da Encyclopédie trouxeram um aprimoramento visual considerável?

Para comprová-lo, basta cotejar rapidamente as pranchas editadas por Diderol com as que constavam nas edições de 1722 e 1730 de Labat, em especial no que se refere à representação das fornalhas e da casa das caldeiras. Na Encyclopédie, a parte superior da prancha \|\| retrata o forno inglês. $O$
2. Como apontou Cecília Helena de S. Oliveira, na Encyclopédie "as gravuras, enquanto expressão da 'poesia narrativa', comprovavam a crença, partilhada por Diderot e D'Alembert, no 'progresso' da arte. O refinamento gráfico, a perfeição de traços e a sensibilidade estética foram recursos utilizados para retratar, com leveza e graça, o mundo de artificios e fetiches que os homens criaram em torno de si próprios. Simultaneamente, porém, segundo D'Alembert, às pranchas caberia registrar conteúdos e detalhes que, se tratados nos verbetes, os tornariam monótonos e cansativos. Assim, os enciclopedistas estabeleceram uma complementariedade entre representa còes verbais e representaçoes figurativas, sem que umas pudessem ser redutiveis às outras" (OLIVEIRA, 1993, pp. 294-295). 
enquadramento adotado pelo gravurista foi o mesmo empregado por Labat (1730) na visualização externa da casa das caldeiras; na Encyclopédie, entretanto, adotouse um artifício visual que permite a observação do funcionamento do sistema de aquecimento propiciado pelo forno inglês. Por sua vez, a prancha IV trouxe, na parte superior, uma vinheta do terno das caldeiras, dos equipamentos aí empregados e do tipo de trabalho realizado, e, na parte inferior, uma planta baixa de todo o espaço da casa das caldeiras. Nesta última, o enquadramento foi novamente idêntico ao de Labat (1722). Contudo, percebe-se três diferenças significativas entre ambas. Em primeiro lugar, em vez de seis caldeiras, estão presentes cinco, o que é uma decorrência da simplificação do processo de cozimento exigida pela adoção do forno inglês; as pranchas de Labat em 1730 já haviam representado esta necessidade. Em seguida, modificou-se a localização da dorna para o recebimento do caldo das moendas; a sua disposição ao lado da grande caldeira tem o propósito de facilitar o fluxo produtivo. Por fim, na gravura da Encyclopédie só está prevista a produção de açúcar purgado, pois não há espaço para o acondicionamento das barricas com açúcar bruto, o que demonstra a intenção de se produzir apenas um produto de alta qualidade. Lançando-se um olhar geral sobre esses três conjuntos de representaçōes visuais sobre a produção de açúcar nas Antilhas (Labat-1722, Labat-1730, Encyclopédie), torna-se evidente a preocupação com o aprimoramento técnico constante.

\section{Considerações Finais}

Como é possivel explicar a atitude pró-inovação técnica de Labat, que, como se pôde observar, encontrou um desdobramento formidável no século XVIlle? Trata-se de uma simples resposta mental às constrições do meio geográfico antilhano e à competição do açúcar francês no mercado europeu? No caso de uma resposta afirmativa à pergunta, estariam validadas assim as hipóteses de John Galloway. De fato, a carência de recursos naturais em certas ithas do Caribe e a concorrência colonial entre França e Inglaterra estimularam os colonos - e os que escreveram sobre a indústria açucareira - a buscarem inovações técnicas para manter, ou mesmo aumentar, a margem de lucro de suas propriedades. Todavia, uma explicação nesses termos não é suficiente para compreender a atitude intelectual de Labat frente às inovaçōes técnicas.

Em realidade, a atitude pró-inovação do dominicano - e dos próprios colonos franceses - guardou um profundo vínculo com o pensamento e a política econômica mercantilista do Ministro das Finanças de Luís XIV, Colbert, no cargo desde 1661. Mesmo após sua morte, em 1683, Colbert continuou sendo uma referência básica não só para a política econômica da Coroa francesa, mas também para as discussões acerca da economia do Reino. Nas palavras do historiador Pierre Deyon, "em função de sua administração ou de seus escritos é que se exprimem os economistas franceses até o fim do reinado de Luís XV. Tem seus adversários, mas também seus discípulos fiéis." (DEYON, 1992, p.49).

Jean Baptiste Labat, não resta dúvida, filiou-se aos últimos, como comprovam as páginas finais do tomo III da Nouveau Voyage aux Isles de 
l'Amerique. Ali, após encerrar as consideraçōes sobre a manufatura açucareira, Labat propôs a introdução em larga escala nas Antilhas de uma série de novos produtos, tais como o chá, o café, a oliva, a cochonilha, e outros mais. Para tanto, a Coroa deveria enviar às Ihas - como já havia feito anteriormente com alguns naturalistas e astrônomos - "homens sábios, hábeis, inteligentes e desinteressados" para auxiliar no desenvolvimento das novas produções. $O$ sucesso de tal política já havia sido comprovado nos tempos de Colbert. Afinal, por determinação do Ministro das Finanças, o estabelecimento das manufaturas de vidraças finas e de cristais na França rompeu o monopólio veneziano sobre estes produtos, o mesmo ocorrendo em relação aos turcos e persas com a produção das tapeçarias de luxo nas manufaturas de Gobelins (Labat, 1722, v.lll, pp.465-503). Numa passagem lapidar, Labat sintetizou o seu ponto de vista sobre a questão:

"nôtre Commerce augmentera à proportion de la quantité \& de la diversité des choses que nous serons en état d'envoyer, ou de vendre aux Etrangers, \& par consequent de faire fleurir nôtre Marine plus qu'elle n'a jamais tait. A quoi je dois ajoûter que l'abondance de nos Marchandises nous mettant en état de les donner à meilleur marché que les autres, nôtre Commerce s'établira sur les rünes de leur, \& nos Ports deviendront les entrepôts du Commerce de presque tout le Monde". (op.cit., p.505)

O trecho acima é de extrema relevância, pois ele evidencia a filiação de Labat às linhas teóricas gerais do pensamento econômico do período. Em primeiro lugar, traz a idéia de que a abundância das mercadorias coloniais francesas possibilitaria a queda dos preços dos artigos tropicais e, conseqüentemente, o avanço do comércio francês "sobre as ruínas dos estrangeiros". Conforme indicou a clássica análise do historiador sueco Eli Heckscher, há uma lógica articulada em se procurar debilitar economicamente os países inimigos: de acordo com os fundamentos do pensamento mercantilista, um Estado só é rico e poderoso se comparado com os seus vizinhos. Nos termos desse historiador, "tal ideologia inspirava-se na concepção estática da vida econômica, na idéia de que no mundo só existia uma determinada quantidade de recursos econômicos, razão pela qual um país podia acrescentar os seus unicamente à custa dos demais" (HECKSCHER, 1983, p.470). Entretanto, isto não significa que os teóricos do período renunciaram à busca da abundância interna do Reino. Seguindo o mesmo caminho aberto por Jacob Viner em sua crítica à interpretação de Heckscher (VINER, 1972), Catherine Larrère demonstrou com muita propriedade a distinção que houve no mercantilismo entre os princípios do comércio exterior, cujo objetivo maior era assegurar o poder político do Reino frente aos países inimigos, e os princípios do comércio interior, que tinha por objetivo garantir a abundância e o bem-estar aos súditos (LARRĖRE, 1992, 101-107).

Ora, as propostas de Labat para o incremento técnico da agromanufatura açucareira francesa se encaixaram perfeitamente nesse esquema mental, pois procuraram aumentar a "abundância" da produção colonial com vistas tanto ao fortalecimento do poder metropolitano no quadro europeu quanto ao crescimento da riqueza dos súditos franceses. Não se pode portanto dissociar a atitude mental pró-inovação técnica de Labat e dos senhores de engenho 
franceses das linhas básicas do pensamento mercantilista francês, cujo expoente máximo foi Colbert.

Se comparado com a fortuna crítica dos livros de Labat, o texto de Antonil teve uma terrível má sorte. Tão-logo publicada, a Cultura e Opulência do Brasil por suas drogas e minas sofreu um seqüestro régio e foi destruída, salvando-se menos de dez exemplares da obra. Como durante todo o século XVIII ela não foi reeditada, sua circulação praticamente não existiu. A primeira edição após o confisco régio, publicada em 1800, esteve sob o encargo do Frei José Mariano da Conceição Velloso. Contudo, o grande objetivo da edição sob os auspícios de Velloso não foi o de recuperar o texto de Antonil em sua positividade, mas sim o de demonstrar como ele descrevia técnicas ultrapassadas que careciam de reformas.

Como se viu em páginas anteriores, o descaso de Antonil em relação às inovações técnicas explica-se pelo próprio escopo de seu livro. $O$ objeto central da obra era a ética senhorial cristã no governo do engenho, o redimensionamento do poder senhorial no comando de um grande número de subordinados, fossem escravos ou homens livres. As considerações sobre as técnicas produtivas, procurando traçar o modo ideal de se fazer açúcar, relacionavam-se diretamente com o plano geral da obra: afinal, o comportamento ideal de um verdadeiro senhor de engenho cristão passava pela garantia de uma produção de açúcar que sancionasse o seu modus vivendi, e que não contrariasse os preceitos básicos do catolicismo romano. Por este motivo, não houve aberturas na obra de Antonil para se conceber o aprimoramento do processo produtivo dos engenhos.

O descaso do jesuíta em relação a técnicas produtivas alternativas poderia ter sido contrabalançado pelo interesse dos senhores brasileiros sobre a questão. Não obstante, os últimos manifestaram igualmente um arraigado desinteresse com o incremento técnico dos seus engenhos. Até o quarto final do século XVIII, a única obra que tratou da produção açucareira tal como praticada no Brasil, e mesmo assim de maneira muito sintética, foi a do beneditino D.Domingos do Loreto Couto (COUTO, 1902, pp. 180-185). Por mais que existisse uma clivagem entre jesuítas e colonos - foram as práticas corriqueiras desregradas dos senhores brasileiros que motivaram o surgimento da literatura moral jesuítica sobre o governo dos engenhos na passagem do século XVII para o XVIII - houve igualmente um profundo vínculo entre o universo mental de Antonil e o universo mental dos senhores de engenho luso-brasileiros.

Para demonstrar tal identificação entre as atitudes intelectuais de Antonil e dos senhores luso-brasileiros, a resposta dos últimos à crise do açúcar brasileiro ao longo da primeira metade do século XVIII é altamente significativa. Como diversos historiadores demonstraram, a crise da economia açucareira nos setecentos teve uma dupla raiz. Em primeiro lugar, a descoberta de ouro no interior do território na última década do século XVII e o enorme afluxo populacional que para lá se dirigiu durante o primeiro quarto do século XVIII acarretaram uma formidável elevação nos preços dos escravos - e também de outros insumos - no Brasil. Além de pagar mais caro pela mão-de-obra, os 
senhores de engenho brasileiros tiveram que enfrentar, desde meados do século XVII, a concorrência do açúcar antilhano (SCHWARTZ, 1988, pp.157-169; FERLINI, 1988, pp.79-93). Frente a esses problemas, quais foram as respostas dos produtores de açúcar brasileiros?

Apesar das lenhas serem abundantes no Brasil - no julgamento de Antonil, "o alimento do fogo é a lenha, e só o Brasil, com a imensidade dos matos que tem, podia fartar, como fartou por tantos anos, e fartará nos tempos vindouros, a tantas fornalhas, quantas são as que se contam nos engenhos da Bahia, Pernambuco e Rio de Janeiro" (pp. 196-198) - , um dos maiores gastos dos senhores referia-se à compra delas. Os gastos com a aquisição de combustível para as fornalhas comprometiam por volta de $20 \%$ dos custos variáveis médios dos engenhos de açúcar no período da safra. $O$ caso do engenho Sergipe do Conde, base da observação de Antonil, é exemplar: entre as safras de 1707 e 1716, as despesas anuais do engenho dos jesuítas com a compra de combustível representaram exatamente 20,1\% dos gastos totais (SCHWARTZ, pp. 191-192). Percebe-se assim o grande grau de otimismo de Antonil na avaliação dos recursos naturais disponiveis para as fornalhas.

O emprego do bagaço de cana como combustivel, em uso nas Antilhas desde o final do século XVII, poderia, portanto, representar uma significativa economia nos custos dos engenhos brasileiros, e, assim, conferir maior competitividade ao açúcar produzido na América portuguesa. Caso esse processo fosse adotado, os únicos investimentos adicionais necessários para aproveitar o bagaço seriam a construção de um galpão coberto para a secagem das canas após a moagem e o deslocamento de um escravo para a tarefa. Ora, salvo alguns poucos casos isolados, os senhores brasileiros pouco se importaram com a adoção de novas fornalhas como um recurso para a diminuição dos custos variáveis dos engenhos.

É importante ressaltar que o uso do bagaço não seria a única resposta "administrativa" possível dos senhores brasileiros à crise do século XVIII. Ele foi tomado como exemplo, pois discutiu-se bastante no presente artigo a questão do incremento técnico das fornalhas. Além do mais, esse exemplo serve também para precisar a natureza da resposta dos produtores brasileiros de açúcar à conjuntura desfavorável da primeira metade dos setecentos.

A ação dos senhores no período concentrou-se basicamente na esfera do poder, relegando a segundo plano um combate gerencial à crise. Como enfatizou Stuart Schwartz, a situação com a qual os proprietários escravistas brasileiros sonhavam era a de "um mundo onde impostos e tarifas governamentais fossem baixos ou inexistentes, onde houvesse sempre um grande número de navios para transportar o açúcar, de modo a reduzir os custos de frete, e onde fosse constante, de boa qualidade e com grande volume a oferta de mão-de-obra africana, para que os custos dessa mão-de-obra permanecessem baixos. (...) Essencialmente, sonhavam com custos e impostos baixos, crédito fácil a juros reduzidos e preços altos para seu produto"(p. 170). Com estes objetivos em mente, os senhores brasileiros traçaram uma polífica articulada para a defesa de seus interesses e privilégios. Tal política incidiu sobre vários pontos: sobre a tentativa de obter a moratória das dividas com os comerciantes, ou, na impossibilidade da moratória, a garantia de que escravos, terras e demais insumos dos engenhos não 
fossem arrestados separadamente; sobre a determinação local dos preços do açúcar, em prejuízo dos comerciantes; sobre a tentativa de impedir a fundação de novos engenhos, sob o argumento de que se fossem estabelecidas novas manufaturas, a lenha disponivel seria esgotada rapidamente. À Metrópole portuguesa caberia o papel de garantir a reprodução das hierarquias sociais que reservavam aos senhores de engenho o posto máximo.

Por conseguinte, não havia nessa política espaço para a possibilidade de se aumentar a produção brasileira em termos qualitativos e quantitativos, com vistas a ganhar a competição contra as colônias francesas e inglesas nas Antilhas. O que interessava era a manutenção do status de senhor de engenho numa conjuntura adversa. Em resumo, a racionalidade econômica que governou tanto a construção do relato de Antonil quanto o comportamento dos proprietários brasileiros no curso da crise do século XVIII buscou basicamente ganhos extra-econômicos, como o poder e a honra acoplados à imagem do senhor de engenho. Afinal, as palavras iniciais da Cultura e opulência do Brasil na lavra do açúcar, citadas à exaustação pela historiografia, não deixavam margens para dúvidas:

"o ser senhor de engenho é fítulo a que muitos aspiram, porque traz consigo o ser servido, obedecido e respeitado de muitos. E se for, qual deve ser, homem de cabedal e governo, bem se pode estimar no Brasil o ser senhor de engenho, quanto proporcionadamente se estimam os títulos entre os fidalgos do Reino."

\section{BIBLIOGRAFIA}

ANTONIL, André João. Cultura e Opulência do Brasil por suas drogas e minas (1711). (Ed. Andrée Mansuy) Paris; IHEAH, 1968.

CANABRAVA, Alice P. "João Antonio Andreoni e sua obra". in :ANTONIL, A.J. Cultura e Opulência do Brasil. São Paulo ; Companhia Editora Nacional, 1967.

O Açúcar nas Antilhas (1697-1755). São Paulo ; Fipe-USP, 1981.

CARDOSO, Ciro Flamarion S. "Propriedade da terra e técnicas de produção nas colônias escravistas da América Latina e das Antilhas no século XVIII" in: Agricultura, escravidão e capitalismo. Petrópolis ; Vozes, 1979.

. Ensaios Racionalistas. Filosofia, Ciências Naturais e História. Rio de Janeiro; Campus, 1988.

CASTRO, Antonio Barros de. "Brasil, 1610: mudanças técnicas e conflitos sociais." in: Pesquisa e Planejamento Econômico. 10(3): 679-712, dez. 1980.

COUTO, D.Domingos do Loreto. "Desagravos do Brasil e Glórias de Pernambuco" (1757). in:Anais da Biblioteca Nacional do Rio de Janeiro. 24: 1-611, 1902. 
DEYON, Pierre. O Mercantilismo (trad.port.). São Paulo; Perspectiva, 1992.

FERLINI, Vera Lúcia Amaral. Terra, Trabalbo e Poder. O mundo dos engenbos no Nordeste Colonial. São Paulo; Brasiliense, 1988.

FRAGINALS, Manuel Moreno. O engenbo: complexo sócio-econômico açucareiro cubano (trad.port.). São Paulo; Hucitec - Unesp, 1987, 2v.

GALLOWAY, J.H. "Tradition and Innovation in the American Sugar Industry, c.1500-1800: An Explanation" in: Annals of the Association of American Geograpbers. 75(3): 334-351, 1985.

The Sugar Cane Industry. An bistorical geograpby from its origins to 1914 . Cambridge; Cambridge University Press, 1989.

GODELIER, Maurice. The Mental and the Material. Thought Economy and Society. (engl.trans.) London; Verso, 1986.

HECKSCHER, Eli F. La Época Mercantilista (trad.esp.) México; Fondo de Cultura Económica, 1983.

JAMESON, Russell P. Montesquieu et l'Esclavage. Étude sur les origines de l'opinion antiesclavagiste en France au XVIIIe. siècle. (1911). New York; Burt Franklin, 1971.

KOSTER, Henry. Viagens ao Nordeste do Brasil (1817). (trad.port.) São Paulo; Companhia Editora Nacional, 1942.

LABAT, Jean Baptiste. Nouveau Voyage aux Isles de l'Amerique. Paris; 1722, 6v.

Voyage du Chevalier des Marchais en Guinée, Isles Voisines, et a Cayenne, fait en $1725,1726 \& 1727$. Paris; $1730,4 \mathrm{v}$.

LARA, Silvia Hunold. "Do singular ao plural: Palmares, capitães-do-mato e o governo dos escravos". in: REIS, J.J.; GOMES, F. dos S. Liberdade por um fio. História dos Quilombos no Brasil. São Paulo; Companhia das Letras, 1996.

LARRÈRE, Catherine. L'Invention de l'Économie au XVIIIe. siècle. Du droit naturel à la physiocratie. Paris; PUF, 1992.

McCLELLAN III, James E. Colonialism and Science. Saint Domingue in the Old Regime. Baltimore; The Johns Hopkins University Press, 1992.

MELLO, Evaldo Cabral de.A Fronda dos Mazombos: nobres contra mascates, Pernambuco, 16661715. São Paulo; Companhia das Letras, 1995.

OLIVEIRA, Cecília Helena de Salles. "A Encyclopédie de Diderot: De Tratado a álbum ilustrado. Observações sobre os riscos de interpretações editoriais". in: Anais do Museu Paulista. Nova Série, 1: 293-296, 1993.

PERROT, Jean-Claude. Une Histoire Intellectuelle de l'Économie Politique, XVIIe-XVIIIe siècle. Paris; Editions de l'École des Hautes Études en Sciences Sociales, 1992. 
PSEUDO-ARISTÓTELES. Económicos (trad.esp.por Manuela García Valdés). Madrid; Editorial Gredos, 1984.

RODRIGUES, José Honório. "A literatura brasileira sobre o açúcar no século XIX". in: Brasil Açucareiro. XIX(5): 466-488, maio 1942.

ROMAIN, M. le. "Sucre". in: Encyclopédie ou Dicionnaire Raisonné des Sciences, des Arts et des Métiers, par une Societé des Gens de Lettres. Tome XV. Neufchastel; 1765.

SAVARY DES BRUSLONS, Jacques. Dictionnaire Universel de Commerce. 3 tomes. Paris; 1741.

SCHNAKENBOURG, Ch. "Note sur les origines de l'industrie sucrière en Guadeloupe au XVIIe. siècle." in: Revue Française d'Histoire d'Outre-Mer. 200: 267-315, 1968.

SCHWARTZ, Stuart B. Segredos Internos. Engenhos e escravos na sociedade colonial, 1550-1835 (trad.port.) São Paulo; Companhia das Letras, 1988.

SHERIDAN, Richard B. "Samuel Martin, Innovating Sugar Planter of Antigua, 1750-1776". in: Agricultural History. 34: 126-139, 1960.

VAINFAS, Ronaldo. Ideologia e Escravidão. Os letrados e a sociedade escravista no Brasil colonial. Petrópolis; Vozes, 1986.

VELLOSO, Frei José Mariano da Conceição (org). O Fazendeiro do Brazil. Tomo I, Da cultura das canas, e factura do assucar. Lisboa; $1798,2 \mathrm{v}$.

Extracto sobre os engenbos de assucar do Brazil. Lisboa; 1800.

VILHENA, Luís dos Santos. A Babia no Século XVIII (1798). Salvador; Itapoã, 1969.

VINER, Jacob. "Poder versus abundância, como objetivos da política exterior nos séculos XVI e XVIII”. in: Ensaios Selecionados (trad.port.). Rio de Janeiro; FGV, 1972. 

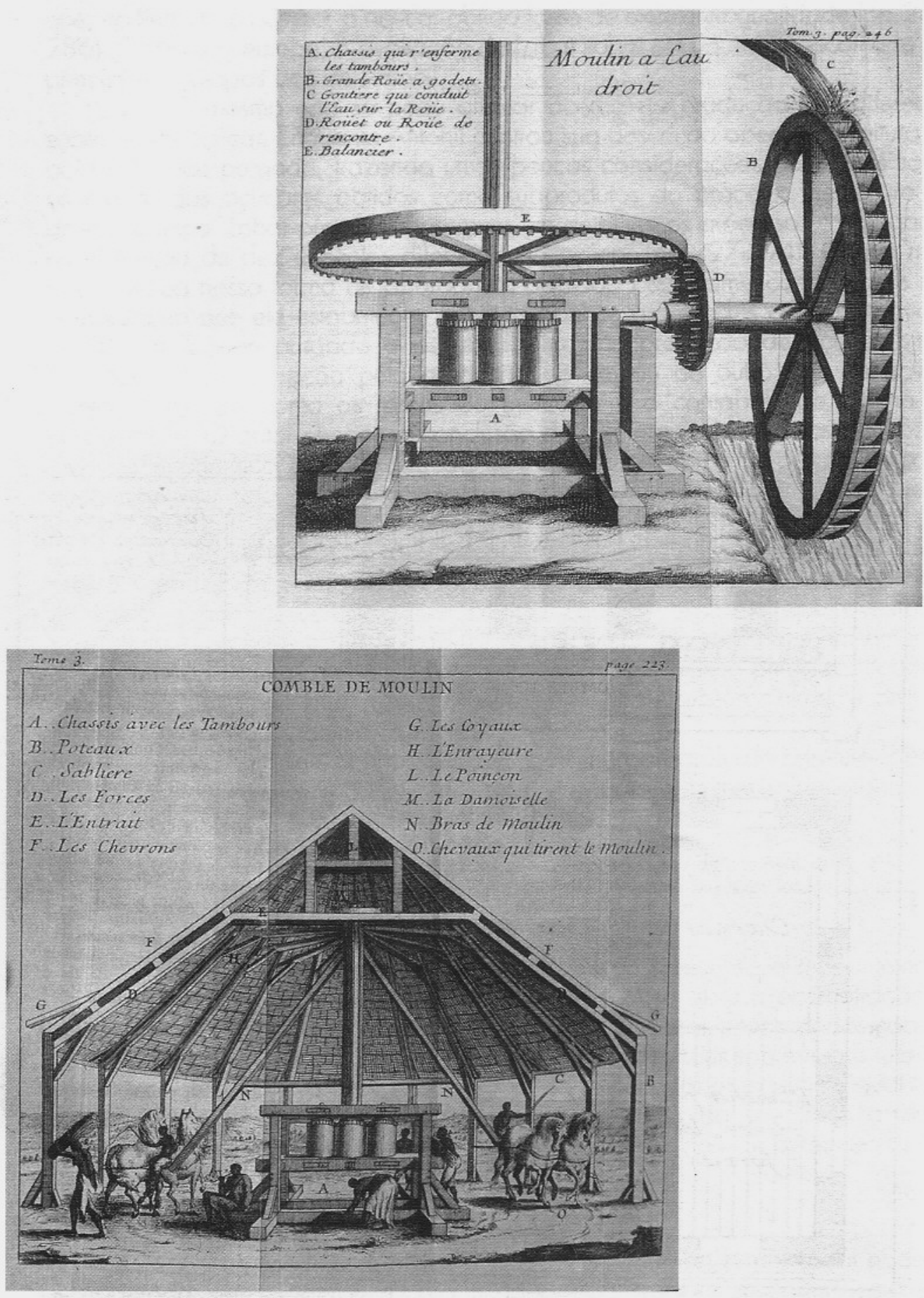

Figura 1. Jean Baptiste Labat, Nouveau Voyage aux Isles de l'Amerique. Paris, 1722, v.lll, p.223 e p. 246: tipos de moenda existentes nas Antilhas francesas. Acervo da Biblioteca do Instituto de Estudos Brasileiros/USP, códice: 7,e,4. 


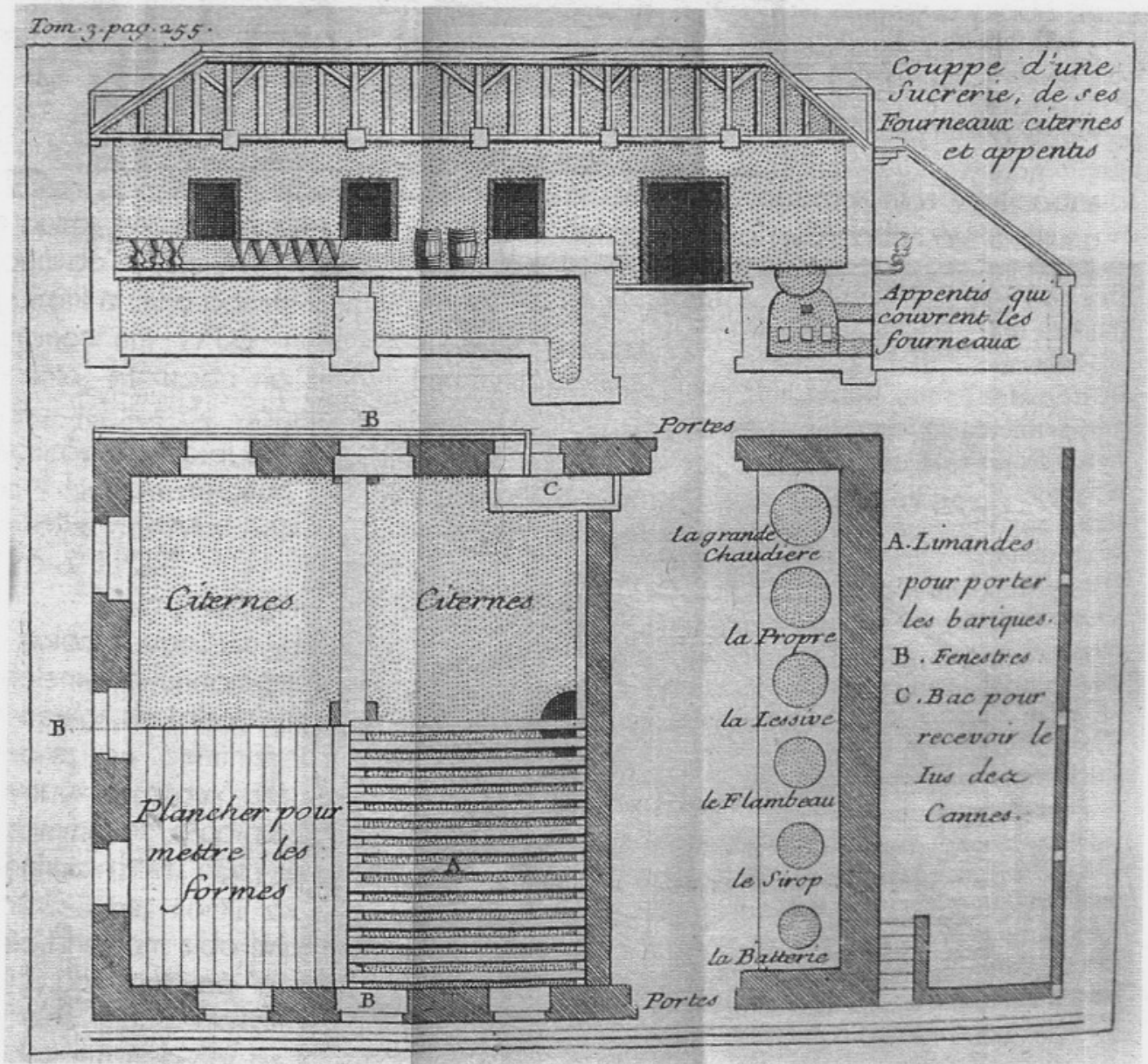

Figura 2. Jean Baptiste Labat. Nouveau Voyage aux Isles de l'Amerique. Paris, 1722, t.III, p. 255: Casa das Caldeiras (Sucrerie). Acervo da Biblioteca do Instituto de Estudos Brasileiros/USP, códice: 7,e,4. 


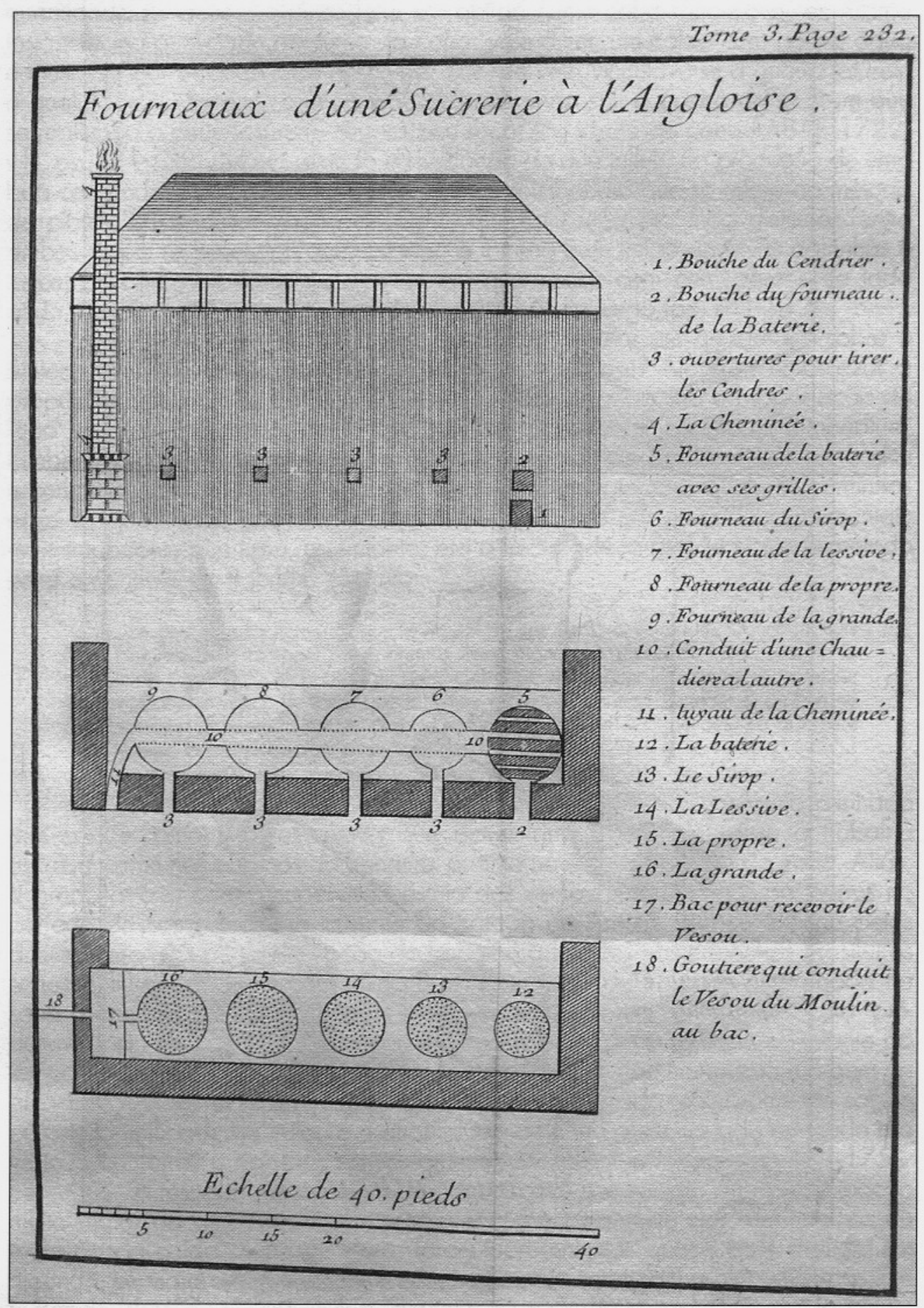

Figura 3. Jean Baptiste Labat. Voyage du Chevalier des Marchais en Guinée, Isles Voisines, et a Cayenne, fait en 1725, 1726 \& 1727. Paris, 1730, t.lll, p. 232: Founeaux d'une Sucrerie à l'Angloise. Acervo da Biblioteca do Instituto de Estudos Brasileiros/USP, códice: 7, b, 10. 


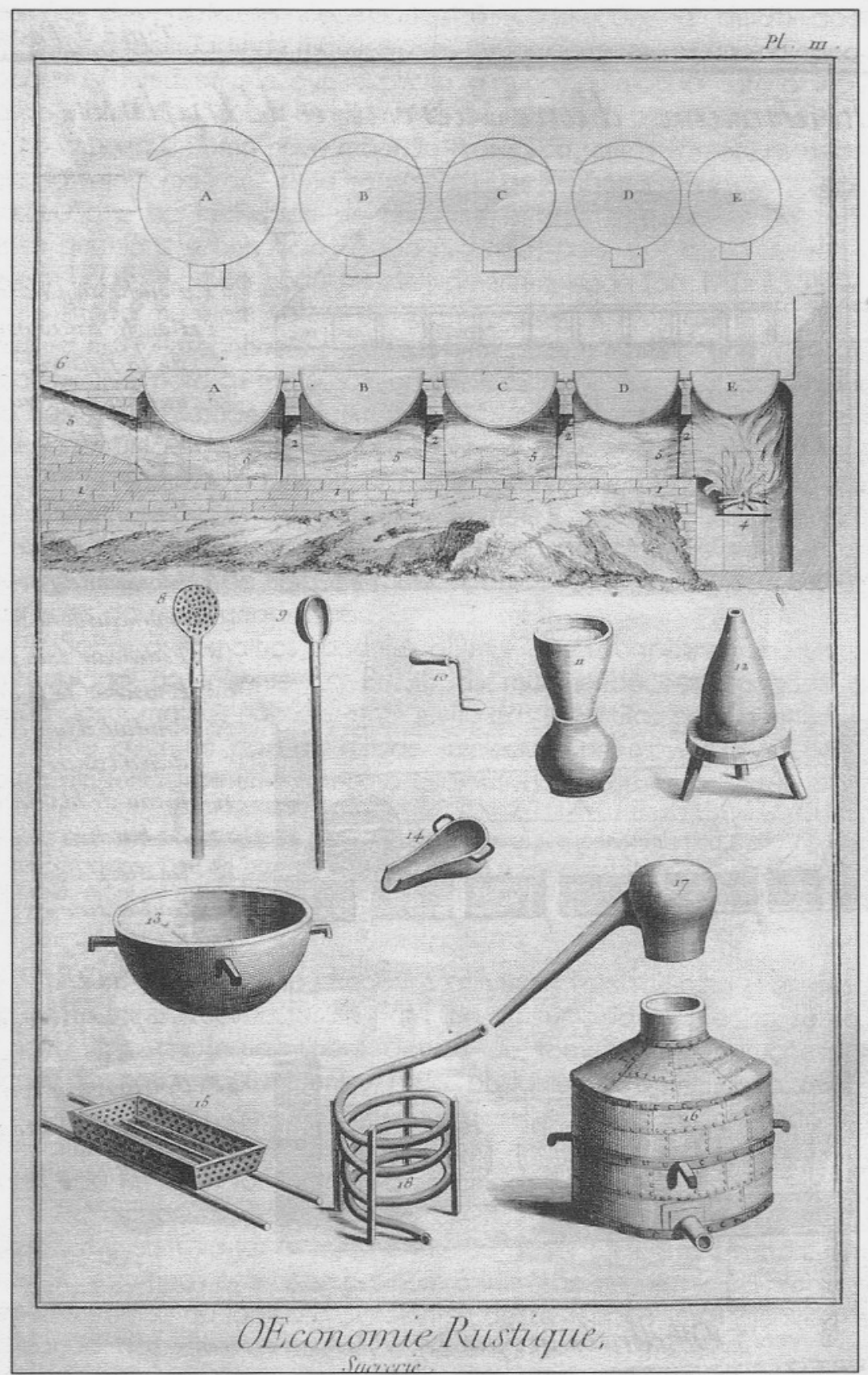

Figura 4. L'Encyclopédie ou Dictionnaire raisonné des sciences, des arts et des métiers, de Diderot et D'Alembert. Compact edition. Paris: Pergamon Press, 1969, vol. IV. Acervo da Biblioteca do Instituto de Estudos Brasileiros/USP, códice: RO34/D555e.

Prancha III. Engenho. Forno Inglês. 


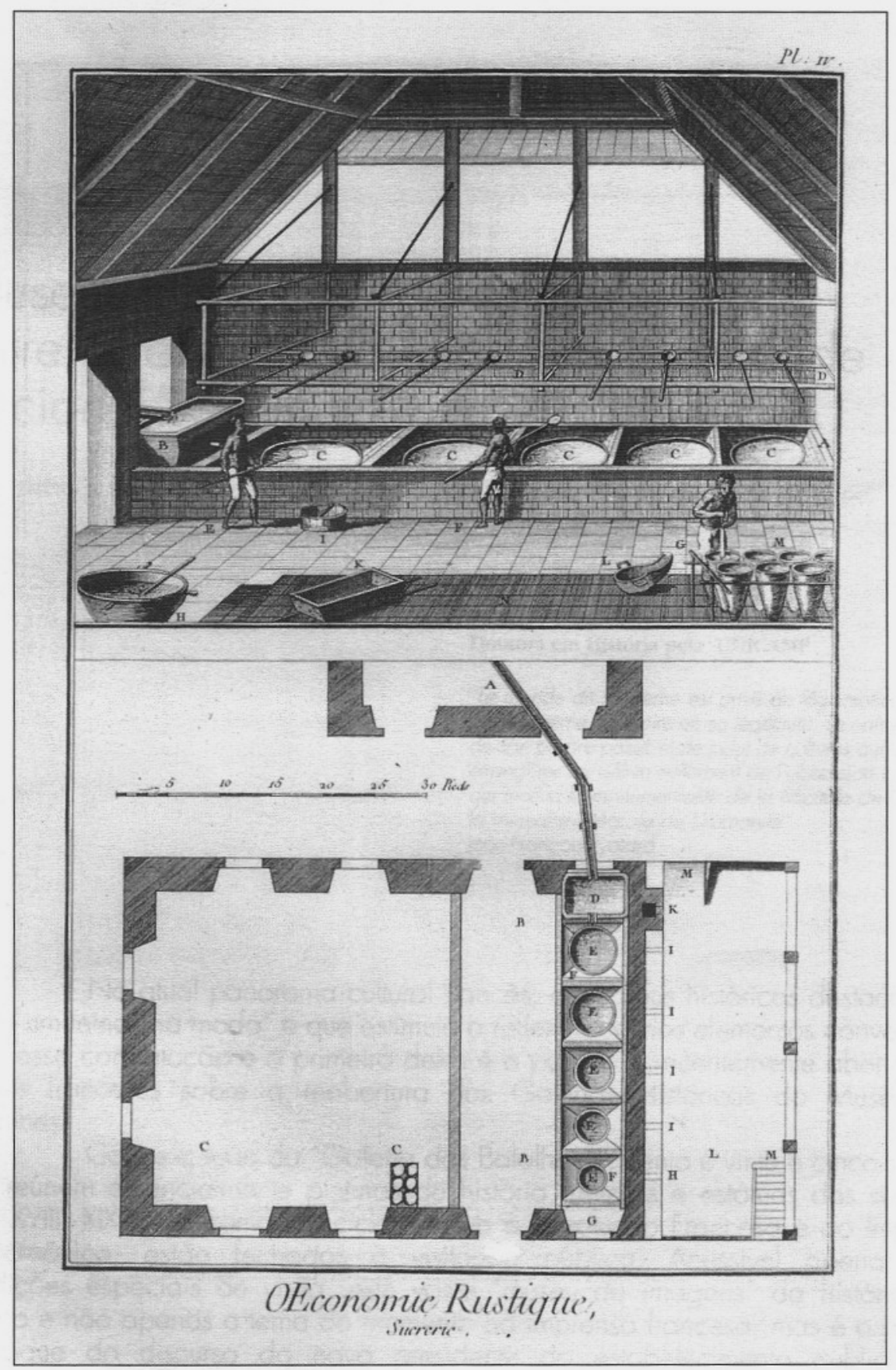

Figura 4. L'Encyclopédie ou Dictionnaire raisonné des sciences, des arts et des métiers, de Diderot et D'Alembert. Compact edition. Paris: Pergamon Press, 1969, vol. IV. Acervo da Biblioteca do Instituto de Estudos Brasileiros/USP, códice: RO34/D555e.

Prancha IV. Casa das Caldeiras. 
Tea and sympathy. A gender strategy in XIXth.century Rio de Janeiro

Tania Andrade Lima

The A. initially sketches a picture of tea and tea ritual in England, the core of the Industrial Revolution, and calls attention to their meanings as a tool for women's liberation. Drawing especially on archaeological evidences supplemented by literary sources, she then directs her analysis to the periphery of capitalism and depicts the introduction of tea in Brazil. The tea ritual, clearly under female authority, according to the English model, particularly among the elite, exhibits however a singular middle class peculiarity in XIXth.century Rio de Janeiro, as it is served in a male space par excellence, the dining room. Such an ambiguity is examined together with other more recent rituals (which have dismissed the original tea etiquette as a rite de passage) from the point of view of gender strategies.

UNITERMS: History of tea. Tea ritual. Gender. Rio de Janeiro: XrXth.century.

Inovações técnicas e atitudes intelectuais na literatura açucareira francesa e luso-brasileira da primeira metade do século XVIII

\section{Rafael de Bivar Marquese}

A analisa duas diferentes atitudes mentais diante das técnicas de produção açucareira nas Antillhas e no Brasil, no começo do séc.XVIII, segundo o registro de dois relatos escritos em francês por Jean-Baptiste Labat (1722) e em português por André João Antonil (1711). Chama a atenção para o problema da racionalidade econômica tal como entendida pelos proprietários escravistas do Novo Mundo na busca da inovação técnica.

UNITERMOS: História do açúcar. Antilhas. Brasil, séc.XVIIl. Inovação técnica. Racionalidade econômica. Labat. Antonil.

Technical innovation and intelectual atititudes in the French and Luso-brazilian literature about sugar in the first half of the XVIllth.century

\section{Rafael de Bivar Marquese}

The A. analyses two different mental attitudes towards sugar production techniques in the Antilles and in Brazil in early XVIllth.century, as registerd by two reports written in French by Jean-Baptiste Labat (1722) and in Portuguese by Andre João Antonil (1711). Attention is called to the problem of economic rationality as endorsed by New World slave-owners looking for technical innovations.

UNITERMS: History of sugar. Antilles. Brazil, XVIIIth.century. Technical innovation. Economic rationality. Labat. Antonil.

Contribuição ao esłudo do vocabulário da habiłação. A palavra casa nos dicionários da Língua Portuguesa

Ieda Maria Alves

A A. empreende o estudo da unidade lexical casa, segundo o registro nos principais dicionários da Língua Portuguesa desde o séc.XVIII. Discute os sentidos originais da unidade léxica, os vários grupos sintagmáticos em que foi sendo alocada e a variedade e mudanças de matizes, conforme os diferentes tipos e finalidades de casa. Ela propõe que a pesquisa lexicográfica seja usada como instrumento para o estudo das transformações sócio-culturais. 